\title{
ETYMOLOGY IN THE EARTH SCIENCES: FROM ‘GEOLOGIA’ TO ‘GEOSCIENCE’
}

\author{
RICHARD J. HOWARTH \\ Earth Sciences \\ University College London \\ 5 Gower Place \\ London, WC1E $6 B S$ \\ r.howarth@ucl.ac.uk
}

\begin{abstract}
The origin and usage through time of geologia, geognosy, geogony, oryctognosy, geology and geophysics, as characterised by their frequency of occurrence in the Google Books Ngram Corpus, is discussed. The English, French, German, Italian and Spanish corpuses used in this study have been normalised over the same timespan using the average frequencies of occurrence of the same set of 'neutral' words in each language (as advocated by Younes and Reips 2019). Use of the term geology is found to predate publication of James Hutton's Theory of the Earth in 1795 by about 100 years; geognosy, oryctognosy and geogony, much less commonly used, became established in the 1780s and began to fall out of use around 1820. The terms geologist, and geognost follow a similar pattern. The emergence of geophysics is a less familiar field: While the phrases physics of the Earth and physical geography can both be traced back to the early 1700 s, geophysics only began to be used in the early 1800 s and did not really become common until about 1860; geophysicist becomes common in German after 1860, but more generally after 1880. The first geophysics-related publications were bulletins from magnetic and seismic observatories and its first dedicated journal, Beiträge zur Geophysik, began publication in 1887, eighty years after the formation of The Geological Society of London. The tems earth science and geoscience, popular today, have steadily increased in their usage since being introduced the 1880 s and 1930 s respectively.
\end{abstract}

Keywords: History of geology, history of geophysics, n-gram, geology, geologist, geologia, geogony, geognost, geognosy, oryctognosy, physics of the Earth, physical geography, geophysics, geophysicist, earth science, geoscience.

\section{INTRODUCTION}

The science of geology gradually developed, from the seventeenth century onwards, as a consequence of a growing interest in rocks, minerals, the disposition of strata, and the nature of mountains. Accompanying this was a desire to understand the nature and causes of world-wide phenomena which depended on invisible forces: magnetism, gravity, earthquakes, the heat of the earth, and atmospheric- and terrestrial-electricity. By the early nineteenth century, the study of these topics had become collectively known as 'geophysics' which, unlike geology, was an essentially instrumentally-based science. In due course, many of the techniques developed in the study of geophysical phenomena came to be employed in the search for minerals and to elucidate geological structures. By the 1920s, this area of application had become known as applied geophysics (Ambronn 1926; English translation 1928).

As all these fields of study evolved, development of new terminology became necessary, and this is explored here. It has recently become possible to quantitatively examine long-term changes in the frequency of word usage by means of what are known as $n$-grams: a 1-gram being a string of characters within a text which are uninterrupted by a space. Normally, this will be a single word, such as geophysics; a 2-gram consists of two 1-grams separated by a space, and so on; thus, a phrase such as the figure of the earth ${ }^{1}$ would be a 4-gram (Michel et al. 2011). Google LLC had a long-running programme to digitize a vast number of books in several languages and to extract all the ngrams, up to and including 5-grams, from them. By 2012, the texts of over 15 million books (12\% of all books ever published) had been digitized and, by using optical character recognition, all the n-grams from over 8 million books in which the scanned text was of sufficient quality were extracted to form the Google Books Ngram Corpus. ${ }^{2}$

For a given language and n-gram, usage frequency is measured as the ratio of the number of occurrences of the n-gram in a year to the total number of words in the corpus for that year. Searches are case-sensitive, so 'Geophysics' and 'geophysics' could be treated as different 1-grams but, in this work, case has been ignored on retrieval (Michel et al. 2011, Lin et al. 2012). Figure 1 shows the variation in the frequency of usage of the terms geology and geophysics, expressed as the annual number of occurrences of the n-gram per million words averaged over the English, French, German, Italian and Spanish corpuses, as a function of time between 1700 and $2000 .^{3}$ The onset of a continuing increase in usage, from about 1796 and 1861 respectively, is evident and presumably reflects a significant growth in the interest in both subjects. The small oscillations in the curves prior to these times reflect variations in the far smaller number of very early publications in the original sample. ${ }^{4}$ 
As these new fields of scientific enquiry began to develop, their practitioners found that in order to aid the description and classification of emerging aspects of the natural world, new terminology was required.

\section{GEOLOGIA}

According to Kidd (1835) and Adams (1938, p. 165), the Latin term geologia first appeared in written form in an English work as a heading ('Geologia. Of Earths') to the first section of the volume on mineralogy (Lovell 1661b, p. 1) in a three-part encyclopaedia of natural history written by the English botanist, zoologist and mineralogist, Robert Lovell (ca. 1630-1690) (Lovell 1661a,b ${ }^{5}$ ), although it was used "not in the sense now attached to it, but in contradistinction to Metallologia" (Kidd 1835, p. 284).

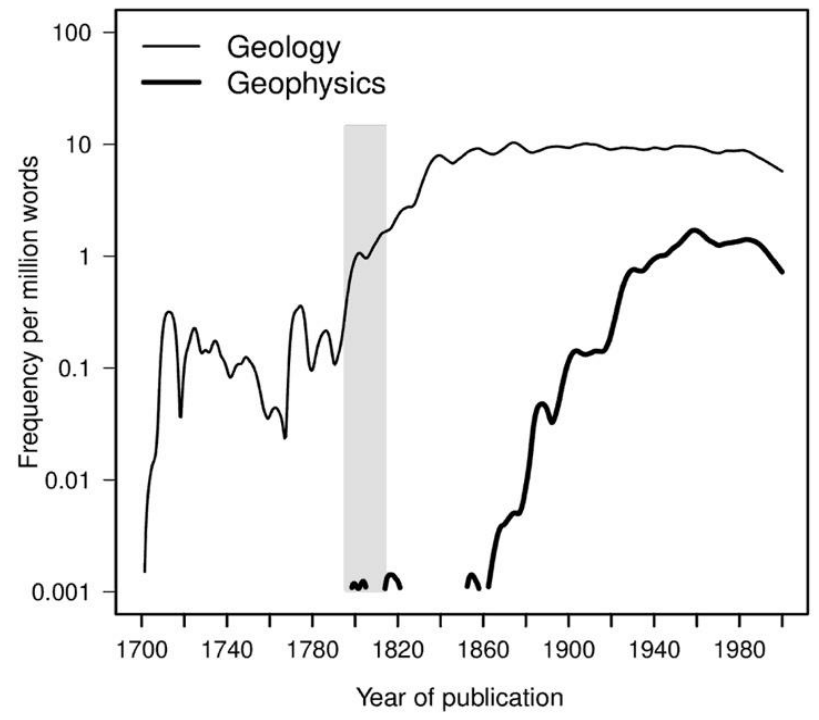

Figure 1. Total relative annual frequency of occurrence of the words geology and geophysics in English, French, German, Italian and Spanish in the Google n-gram database of works published between 1700 and 2000 (see note 3 for details of calculation). The shaded rectangle indicates the beginnings of historical geology from the publication of James Hutton's Theory of the Earth (1795) to William Smith's Map of the Strata of England and Wales with a part of Scotland (1815).

However, Lovell appears to have been anticipated by use of the word giologia by the Italian natural philosopher, bibliophile and assiduous collector of plants, animals, minerals and fossils, Ulisse Aldrovandi (1522-1605), who lived in Bologna and spent his life and all his wealth collecting for 56 years. By the time he had his lawyer draw up his will in 1603, his Library contained over 4000 volumes and over 800 manuscripts, and his Museum (established in 1547) contained, 4000 fossils and minerals, and thousands of preserved plant and animal specimens (Vai \& Cavazza 2006, pp. 47-8). ${ }^{6}$ Setting out what should happen to his collections after his death, he is recorded as having said that:

La Biblioteca penes tabulas, seu indices, che saranno 20 volumi in circa, \& anco la Giologia, ovvero de Fossilibus; poi la Botanologia, \& Zoologia [The Library with tables or indices will be about 20 volumes, and likewise Geology, or rather Fossils; then Botany and Zoology] (Fantuzzi 1774, p. 81).

At that time, fossil meant any object found in the subsurface which was not obviously a mineral. In the quotation above, Giologia was evidently intended to mean 'the science of fossils', on a par with Botanologia and Zoologia (Vai 2003).

Adams (1838, p. 166), suggested that since the word giologia did not appear elsewhere in Aldrovandi's written or printed works, and his will remained unpublished for 170 years, his use of the term had little obvious influence during the 16th Century. However, it is known that from 1554 he taught at the University of Bologna and during his lifetime corresponded widely, rapidly establishing "a full network of correspondence and exchanges with the leading natural scientists in Europe" (Vai \& Cavazza 2006, p. 47). It may well be as a result of this that Lovell became aware of the term giologia, since his own treatise, concerning the medicinal properties of 'earths,' is replete with citations of Aldrovandi as a source of information.

It is a short step from giologia to geologia, which appeared in 1663 in the title of an English translation of a Danish book concerning a Norwegian earthquake which had taken place in 1657 (Eschot 1663). A few years later, the term Geologi (Latin), meaning geologists, ocurred in a book on China, published in 1667 by the German Jesuit scholar, Athanasius Kircher (1602-1680) (Kircher 1667, pp. 136, 205; 1986, pp. 125, 198).

It was suggested by Dean (1979) that use of the word geologia preceded Aldrovandi by some 130 years, first appearing in a fifteenth century work in praise of books, written in Latin by the English cleric Richard Aungerville (1287-1345), also known as Richard de Bury. Although his original manuscript, known to have been written in 1345, 
has been lost, thirty-one manuscript versions of the work ranging from $\mathrm{ca}$. 1370 to 1478 still exist, in varying degrees of completeness. However, both the Latin phrase in question (if given) and its translation vary according to the different translators: The most authoritative translation, by the American classicist Andrew Fleming West (1853-1943) gives details of all of them (de Bury 1889, vol 2):

'nor is this faculty to be numbered among the sciences, though by an appropriate word it may be called geology' (de Bury 1832, p.75); the translator, John Bellingham Inglis (1780-1870) noted (p. 145): 'Page 75. "geology" - The earliest authority I have met with for this word; and here it is but a poor joke - an earthly science.'

'Nec est haec facultas inter scientias recensenda, quam licet geologiam appropriato vocabulo nominare.' (my emphasis; de Bury 1861, p. 144); the translation is identical to Inglis's (p. 145).

'Nor is this faculty which we may call by a special term geologia or the earthly science' (my emphasis; de Bury 1888, p. 219).

'nec est haec facultas inter scientias recensenda, quam licet geologiam ${ }^{*}$ appropriato vocabulo nominare.' [Side-note '* geologicam C, geneologiam in geologiam corr. D.'] (my emphasis; de Bury 1889, vol.1, p. 90). C and D here refer to the 1440 and 1430 manuscripts of the four primarily used by West in his translation (see de Bury (1889, vol. 3) for discussion).

Adams (1938, p. 166) commented on de Bury (1888), that it was in this work that:

"the word "geologia," it is believed, made its first appearance in the literature. It was apparently invented, if this term may be used, by de Bury, who used it in an entirely different sense from that in which it subsequently came to be employed. By it, he designated the study of Law, which faculty, he says, "We may call by a special term Geologia or the earthly science," in antithesis to the sciences which aid in the understanding of divine things, comprehensively speaking, Theologia.' [emphasis as in original].

Dean consequently seems to have been in error. It is evident that by the nineteenth century, when the above translations were written, the meaning of 'geologia' was equivalent to the English term 'geology,' and this meaning began with Aldrovandi's work, as described by Vai (2003) and Vai and Cavazza (2006). Inglis and his fellow translators looked back from their nineteenth century perspective and imputed a meaning which it did not have in the fourteenth century.

In the English-speaking world, geologia probably reached a far wider audience when it appeared in 1690 in the title of a book by the English cleric Erasmus Warren (d. 1718), Rector of Worlington, Suffolk, written as a refutation of the ideas of his fellow-countryman, the theologian Thomas Burnet (1635?-1715). The latter had argued in his Theory of the Earth (Burnet: Latin editions 1681, 1689; English editions 1684, 1690) that the account of the creation of the Earth as described in the biblical Book of Genesis should be taken literally. However, Warren regarded Burnet's account as too simplified, believing, for example, that evidence suggested that there could not have been enough water in the oceans during Noah's Flood to enable all the mountains to be covered. He summarized his thinking as follows:

[T] he Manner of the Earth's Rise . . is supposed to have proceeded thus. The whole matter of the Earth and sublunary Heavens being confusedly blended together, in one fluid Mass or Chaos; the grosser and heavier parts thereof sunk down to the middle of it (as to the Centre of their Gravity) and constituted and [sic.] interior Orb of Earth. The rest of the Mass about it, by the same Principle of Gravity, was divided into two Orders of Bodies; the one Liquid, and the other Volatile. The Volatile mounting above the Liquid, constituted the Air: The liquid mass swimming below (and incircling the inward Earth aforesaid) contained in it all Liquors originally belonging to the Earth. These terrestrial Liquors are of two kinds chiefly; either fat, oily, and light; or else lean, and more earthy. The lean and earthy Liquor made up the Element of common Water: The Oily Liquor (which arose out of the Water as it purged it self) got above it, and floated upon it. ... But this Body of the Air being at first very muddy and impure, through abundance of terrestrial Particles that, as fast as they could free themselves from the Air with which they were mingled, and in which they were intangled, they sunk downward: And meeting, in their descent, with the Oyly Liquor on the face of the Deep, there they stuck; and incorporating with that unctious Substance, made a certain Slime; or a fat, soft, light Earth, spread upon the Waters: Which growing thicker and thicker, by a continual accession of more terrestrial Particles, sliding down still out of the Air, as it purify'd it self; at last it came to its just Dimensions. And then waxing more dry and stiff, and firm and solid, in fine it attained to its due Consistency, and so became the First habitable Earth [emphasis as in original]. (Warren 1690, pp. 46-48).

Burnet took exception to this and a vigorous debate ensued which persisted for some years, thus ensuring that the new word geologia was noticed 


\section{GEOLOGY BEGINS}

The term geologie appeared in 1695 in an explanation and defence of the theories of the French philosopher René Descartes (1596-1650) published by his fellow-countryman Pierre Cally (1630-1709), a philosopher and theologian. Cally's book included chapters on the World (Cosmologie), the Earth (Geologie), Water (Hidrologie), the Sky (Uranologie) and Mankind (Antropologie). The section concerning geologie consisted of six parts: (1) a synopsis of Geography; (2) a discussion of the nature of terrestrial fire, how it arose, how it maintained itself, and its effects (this included the nature of earthquakes, a burning-glass ${ }^{7}$ and gun-powder); (3) the nature of magnetic bodies, such as the compass and iron; (4) Salts; (5) Oils; and (6) other matters the Earth contained within itself, and which mankind used, such as silver, stone, metals and similar bodies (Anonymous 1697).

In 1735, the English instrument-maker, author, lecturer and ardent Newtonian, Benjamin Martin (1704/5-1782) published a 'philosophical grammar' in four parts, the contents of which were summarised on the title page of the book. His synopsis for the last part reads:

PART IV. GEOLOGY, containeth a philosophical View of the terraqueous Globe, in all its Parts and Productions; as Minerals, Metals, Stones $\& c$. The Laws of Fluids; the Sea, its Tides, $\& c$. Of Rivers, Springs, $\& c$. Of Vegetation, and the Nature of Plants, Trees, \&c. Of the Parts of animal Bodies; and a Survey of the nature of Beasts, Birds, Fishes, Insects, Reptiles, Shell-Animals, \&c. (Martin 1735, p. i). ${ }^{8}$

However, in the first chapter of Part IV of the book, he defined Geology as:

A Discourse of the Earth in general, or its terraqueous Globe, as consisting of Land and Water; from the Greek words Гí,

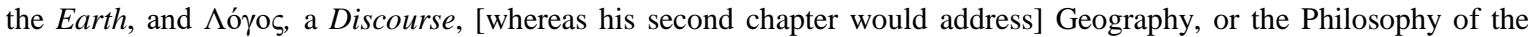
Constitution, Texture, and constituent Parts of the Earth, describing the various Stratas of Earths, Fossils, Minerals, Metals, Stones and other subterraneous Substances [emphasis as in original] (Martin 1735, pp. 189, 205).

His book is written in the form of a dialogue between a pupil ('A') and his master ('B') and it covers many topics. The following extract regarding the "internal Make and Constitution of the Globe of our Earth" provides insight as to the state of knowledge in 1735:

A. [W] hat I would know is, of what the internal solid body of the Earth doth consist?

B. To this I can only answer, that so far as it is within our Scrutiny near the Supersicies, we find it to consist of different Strata, or Layers of Earth, Minerals, Metals, Oars [sic.], Stones, and various other compound Bodies both hard and soft: But what the more internal Parts, or Composition of it may be, we can tell but very little concerning: However the deeper you go, the solider and more compact you find its Matter to be, and the more firmly and strongly does it cohere together; yet it is very certain that within the Entrails of the Earth, are many Hiatus's, Recesses, Windings, Conveyances, and vast Receptacles of Water, sulphureous Substances, $\& c$. which are often the Cause of Earthquakes, and supply Volcanoes with their fiery Eruptions, as Mount Ætna, \&c.

A. What do you suppose to be in the very Middle of the Earth; that is, in and about its Center?

B. No Body can certainly tell; the Earth's Center is near 4000 Miles from us, and we can penetrate towards it but a few Fathoms; how very unlikely then is it, we should know any Thing at such a vast and impervious Distance? However the learned Dr. Halley ${ }^{9}$ has made it very probable, that a great magnetic Body, or Load-stone,${ }^{10}$ doth possess the central Parts of the Earth; which occasioneth the Variations and Declinations of our magnetic Needles, which always conform themselves to the Site and Direction of this central Magnet, or Load-stone; which is supposed to deviate from the North and South points, and from the horizontal Position, with Respect to us.

A. If that be so, it is very wonderful, and a noble Discovery: But, pray, what is it binds the several Parts of the Earth, or makes them cohere so closely together?

B. The Coherence of the Earth is entirely owing to the Power of Gravity, or the Weight of its constituent Parts; whence, as I before said, it is reasonable to believe the most weighty and solid Bodies lie nearest to the Center of the Earth, as being the Center of Gravity it self.

A. Well then, since the more interior Parts of the Earth are so little known, we leave them, and content our selves with what is to be known near the Supersicies of it on which we live; and, pray, what do you first observe thereof?

B. That it does consist of different heterogenous Bodies intermixed with one another, of different specific Gravities, disposed in Manner of Beds, which are called Strata, or Layers of Earth, Stones, Minerals, \&c. one under another.

A. Pray in what Order do these Strata, or Beds of Earth, \&c. lie among themselves?

B. That they do not lie in Order of their specifick Gravities, is evident (and so not every where alike) from the Order of those observed in digging a Well at Amsterdam 232 Feet deep; which was thus, 7 Feet of Garden Mould; 9 of Turf, or Peat; 9 of soft Clay; 8 of Sand; 4 of Earth; 10 of Clay; 4 of Earth; 10 of paving Sand; 2 of Clay; 4 of white Loam; 5 of dry Earth; 1 of muddy Earth; 14 of Sand; 3 of a sandy Clay; 5 of Sand, mixed with Clay; 4 of Sea Sand, mixed with Shells; then 102 of Clay together; and lastly, 31 of Loam: Thus you see the different Make of the outwards parts of the Earth, which is very different in different Places.

A. Pray how came the Disposition of those various Strata, or Beds of Earth and Minerals?

B. This is not known as to the Time; some say at the Creation, others at the Flood; others supposed in the chaotick State of the Earth the heavier Bodies subsided, and lay in this Order by the Laws of Gravitation; but Experience rather contradicts than confirms this Hypothesis.

A. What Distinction, or Division, do you make of earthy Substances or Bodies? 
B. They may be reduced to these general Heads: 1. Earths. 2. Ores. 3. Fossils. 4. Minerals. 5. Metals. 6. Stones. 7. Extraneous Bodies or Substances.

A. What do you include under the first general Head of Earths?

B. All those softer earthy Substances we call Clay, Loam, Marl, Sand and different Species of Earths, as Terra Japonica, Lemnia, Armenia, \&c... .

A. What do you include under the second Head of Ores?

B. Those Earths which contain considerable Quantities of metallick Particles; being that which is dug out of Mines, and whence Metals are extracted, and is dominated accordingly, as Gold-Ore, Silver-Ore, \&c. . . . .

A. What terrestrial Bodies do you intend by Fossils?

B. Though FOSSILS be a general Name for every Thing which is dug out of the Earth; yet I intend thereby, 1. Salts, 2. Sulphurs, and such like Bodies, which cannot be so well reduced to the Heads of Minerals, Metals, and Stones [emphasis as in original]. (Martin 1735, pp. 206-210).

The book was evidently well received: a second edition followed in 1738, and an Italian translation was published in Venice in 1750. Although a work by Pierre Massuet (1698-1776), a French physician living in Amsterdam, contains an identical definition of 'La Géologie,' (Massuet 1752, p. 73), the wording throughout is so similar to Martin's that it could well be a plagiarised work. However, an article on 'Géologie', in a volume of the Encyclopédie Méthodique otherwise devoted to agriculture, places it in a more familiar context: "Geology. This name is given to a science whose object is to make known the nature of the layers of the earth and the phenomena they present" (Tessier et al. 1796, pp. 546-547). By 1812 it had become established that:

\begin{abstract}
The term Geology has been applied in two different senses. [1] Naturalists have been always fond of speculating about the original formation of the earth, and about the changes which it has undergone since its original creation. Accordingly, various fanciful theories have been constructed in succession, either founded entirely upon the imagination of the constructor, or partly upon imagination, and partly upon the account of the creation contained in the Old Testament. These whimsical hypotheses have been dignified with the title of theories of the earth, and the term geology has been very frequently applied to them. . . [2] [A]n account of all the stony masses which compose the crust of the earth; the order in which they lie with respect to each other, and with respect to the substances which they contain. . . To distinguish this important branch of science from the absurd speculations about the formation of the earth, Werner ${ }^{11}$ has given it the name of geognosy [emphasis as in original]. (Thomson 1812, pp. 85-6).
\end{abstract}

\title{
4. A WERNERIAN INTERVAL: GEOGNOSY, GEOGONY, ORYCTOGNOSY
}

In Frank Dawson Adams book The Birth and Development of the Geological Sciences (1938), he noted that the term geognosy, popularized by the lectures of the German mineralogist and economic and structural geologist Abraham Gottlob Werner (1749-1817) during his forty years of teaching at the Freiberg Mining Academy (Bergakademie), and through its appearance in his books, such as Neue Theorie von der Entstehung der Gänge, mit Anwendung auf den Bergbau [New theory on the formation of veins: with its application to the art of working mines] (Werner 1791a, pp. xiv, $x x$, 224), was anticipated by his fellow-countryman, the physician and geologist Georg Christian Füchsel (1722-1773), who had used the words scienta geognostica in an article written in Latin (Füchsel 1761; II, p. 209).

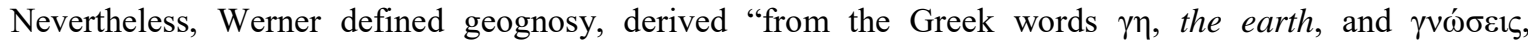
knowledge" (Jameson 1830, p. 389), as a purely observational science, concerning what was known of "the nature of the Earth in its totality" in contrast to: Oryctognosy, "the science of the determination of minerals" ${ }^{12}$; Mineral chemistry, "the chemical composition and analysis of minerals"; Geographical mineralogy, "the regional geology of specific places, particularly with respect to rocks and ore deposits"; and Economic mineralogy, "the characteristics of minerals and their processing for the benefit of humanity". ${ }^{13} \mathrm{He}$ regarded geology as having been more speculative in nature.

It is interesting that shortly after Füchsel's publication, the German chemist Johann Heinrich Pott (1692-1777) introduced the term lithogeognosia, meaning "the knowledge and processing of the common simpler stones and earths" in Pott (1746, p.7), which could be regarded as an early work on geochemistry. It was translated into French as lithogéognosie in 1753 and into English as litho-geognosy in $1765 .{ }^{14}$

Further examples occur in the English translation, ${ }^{15}$ A geognostical essay on the superposition of rocks (Humboldt 1823b), of a work in French by the German traveller and geologist, Friedrich Wilhelm Heinrich Alexander, Baron von Humboldt (1823a), which mentions "geogony, or historical geology" (p. 261); "oryctognosy (or descriptive mineralogy)" (p. 8); and states that "True geognosy describes the exterior crust of our globe such as it exists in our days" (p. 6).

The view that 'geology' encompassed many things, including geognosy, is reflected in an article by the Scottish geologist Robert Jameson (1774-1854) on Mineralogy, in The Edinburgh Encyclopedia (1830), which began with a short outline of the history of geognosy: 
Geognosy ... This important branch of natural history makes us acquainted with the structure, relative position, materials, and mode of formation of the mineral masses of which the crust of the earth is composed. The term geognosy ... has been confounded with orology, which instructs us regarding the physiognomy of mountains, with geogony, which is purely hypothetical, consisting of very abstract speculations regarding the original formation of the earth; also with geology, which, however, has a more extensive signification, for the word hoyos [Eng: reason or cause] comprehends the whole science, or rationale of any subject, and therefore geognosy is only a branch of geology. Geology, indeed, according to Werner, comprehends not only geognosy, but also geography, hydrography, meteorology and geogony [emphasis as in original]. (Jameson 1830, p. 389). ${ }^{16}$

It is interesting that although the introduction to the English translation of Humboldt (1823a) (Humboldt 1823b, pp. 1-84) is replete with the word geognost and its plural, including the statement "Geognosts, who are devoted to the study of the laws of unorganized nature ..." (pp. 4-5), it also contains references to geologists (pp. 8, 28). ${ }^{17}$

Figure 2 shows the relative frequency with which the terms geology, geognosy, geogony and oryctognosy occur in the Google database between 1700 and 2000. Geology has been in use the longest but, as has been shown, its meaning has gradually changed with time. Geognosy, geogony and oryctognosy first appear in the database between 1768 and 1787, just before the era of 'historical geology' began, reaching a maximum usage between 181927 , but it thereafter declined. ${ }^{18}$ Even so, 'geognosy' took a long time to die out.

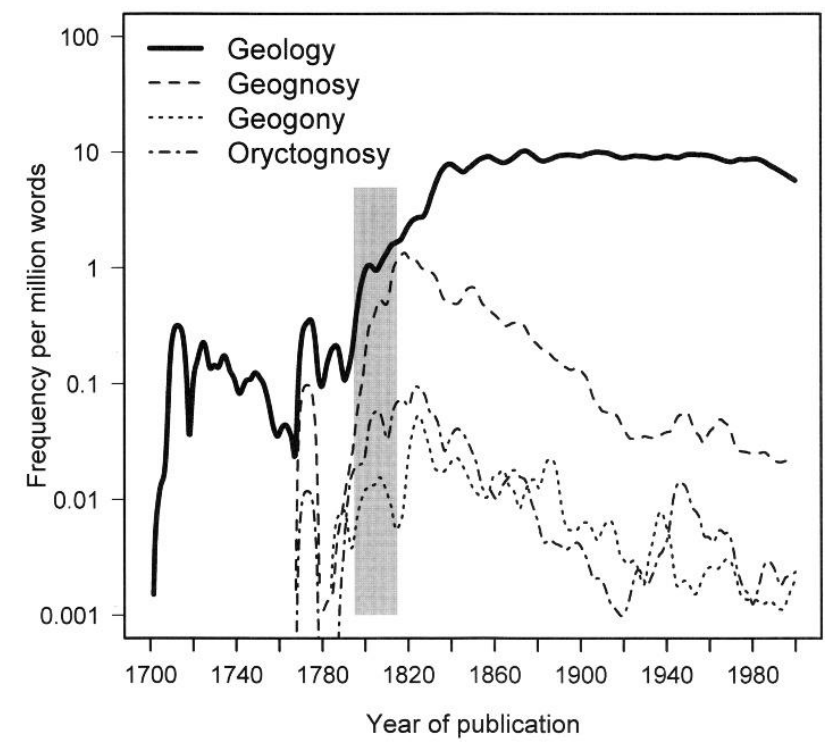

Figure 2. Relative annual frequency of the words geology, geognosy, geogony and oryctognosy (including their equivalents in French, German, Italian and Spanish) in the Google n-gram database between 1700 and 2000. The shaded rectangle indicates the beginnings of historical geology, as in Figure 1.

Klemun (2018) notes that Glocker (1839, p. 5) explained the difference between geognosy and geology in that while the former "limits itself to the spatial juxtaposition of mountain ranges, geology investigates the origin of and changes in these ranges in successive periods." However, Geikie $(1879,213,220)$, regarded geognosy as "an Inquiry into the Materials of the Earth's Substance." But by the turn of the nineteenth century, its meaning had narrowed: "in this department of geological enquiry petrographical research has been greatly pursued and extended," (Geikie 1902, p. 637) and thereafter it appears to have become restricted to petrographic studies. Hunt (1860, vol. 3, p. 364) said of oryctognosy that it was "synonymous with the English term Mineralogy. It is never used."

\section{GEOLOGY RETURNS}

The Geological Society of London, the oldest of its kind in the world, was founded in $1807,{ }^{19}$ its members resolving in March 1810

to publish the more important communications made to the Society, but not at stated periods, the title to be the Memoirs of the Geological Society; ... Early in the following year it was resolved, that the term Transactions be substituted for Memoirs. (Woodward 1908, p. 43).

The Transactions began publication in 1811 and continued intermittently until 1856, having been largely replaced by the regularly-published Quarterly Journal of the Geological Society of London which began in 1845 and which in 1971 became the still-continuing Journal of the Geological Society.

Not long after the formation of the Society, the word 'geology' appeared for the first time in the title of an English book: An introduction to geology, by the agriculturalist and geologist Robert Bakewell (1767-1843), an applied geologist who, like William Smith, never became a Fellow of the Society. In contrast to the Wernerian terminology, use of 'geology' began a steady increase just before 1800 which only levelled-off after 1840. Bakewell 
(1828, p. 1) regarded "the most important objects of geological research" as "What are the substances of which the Earth is composed? What is the order in which they are arranged? What are the changes they appear to have undergone? By 1872, its definition had changed yet again:

it confines its attention to a description of the solid crust of the earth, and to the elucidation of those forces and causes which have produced the changes the surface of our planet has undergone . . The division of the subject we propose is the following:- - 1. Physical Geology . . . 2. The Geological Systems . . . 3. Mineralogy and lithology . . . Under the general term Geognosy is included all that can be said in relation to the structure of the matter composing the earth's crust .. . The rock-masses may be treated of as to their mineral, their internal structure, and those characters which may be determined by handling specimens, such as texture, construction, hardness, etc. All this is Lithology. Petrology describes the larger characteristics of rock; the relative positions they occupy, and the disturbances they have undergone ... A study of fossils is of the greatest importance, and this has received the name of Palaeontology. Mineralogy is a further subdivision of Lithology [emphasis as in original]. (Wallace 1872-1875, vol. 3: pp. 3, 385).

\section{GEOPHYSICS}

Once the science of geology had become established, when did 'geophysics' arise? The word 'physics' is considerably older than one might imagine and is believed to be derived from the Greek $\varphi v \sigma l \alpha$ (meaning nature or matter). It was originally regarded as synonymous with 'natural philosophy' and is generally thought to have originated with the ancient Greek philosophers, such as Aristotle, Pythagoras and Plato. Pythagoras, for example, was held to be skilled in "contemplative physics or natural science" (Gale 1672, p. 171).

By the seventeenth century, the idea of 'physical geography' had also begun to emerge (e.g. Desmarest 1757, pp. 613-624) and fleeting references to 'terrestrial physics' likewise began to appear, such as in a book by the French Cartesian philosopher, Gilles de Launay (or De L'Aunay; dates unknown), who lectured on the subject in Paris. In discussing subdivisions of 'physics' he wrote: "Celestial physics explains the nature of the heavens and stars, and elementary or terrestrial physics examines sublunary bodies" (Launay 1667, p. 11), ${ }^{20}$ a view which would persist for the next century (Paulian 1769, p. 194). A more detailed categorization is found in a book published by another Frenchman, Pierre-Sylvain Régis (1632-1707). While he did not use the exact phrase 'physique terrestre' [physics of the earth] in his work, the heading to the book's fourth section reads: "Physics or the knowledge of natural bodies, $\&$ their properties. Fourth Book. On the nature and properties of terrestrial bodies in general" (Régis 1691, p. 113). ${ }^{21}$ He went on to describe the nature of water, air, oil, salt, hardness (which included discussion of the nature of metals, minerals, stones, the lodestone, amber and jet) and fire (including the nature of gunpowder and terrestrial 'underground fire').

At the turn of the eighteenth century, the potential of physics to reveal something of the Earth at a global scale was brought to public attention by the English scientist Edmond Halley (1656-1742), when he used isolines ('contours') to summarise and illustrate the results of numerous measurements of magnetic declination made during his Atlantic voyages of 1698-1701 (Barraclough 1985; Thrower 1978, 1981). As Humboldt remarked:

It was a happy undertaking of Halley's [1701] to connect graphically by lines or curves all points on the map where the magnetic declination was the same. Clearness of representation, and the advantage of gaining a general view of the connection of detached results, were thus first introduced. (Humboldt 1858a; English translation 1868, p. 60).

By the end of the century, the phrases 'physique terrestre' (French) and 'fisica terrestre' (Italian) had also come into use. This suggests that this new field of study was beginning to be recognized in several countries: the phrase 'Fisica terrestre, e celeste' [terrestrial and celestial physics] occurs in passing in a late eighteenth century Italian periodical (Occhi 1757, p. 382) and 'La physique terrestre' appears in a dictionary from the same period, published by the French physicist, Aimé-Henri Paulian (1722-1802), who taught at the Jesuit College in Avignon in 1761:

Terrestrial Physics, ... requires careful study. The inside of our Globe first provides the spectacle of Underground Fires, Earthquakes caused by Electricity, Fossils, that is to say, Metals, the Lodestone, Ordinary Stones \& precious stones, etc. (Paulian 1761, p. 46). ${ }^{22}$

Similar views were expressed by Paulian (1770). 'Physique terrestre' also occurs in an article by the Swiss geologist Jean-André de Luc (1727-1817) in the early French scientific journal Observations et Mémoires sur la Physique, sur l'Histoire Naturelle et sur les Arts et Métiers. ${ }^{23}$ Usage of the term in Germany and Italy continued into the nineteenth century and can be found in publications by Pilla (1823), Naumann (1824), and Avogadro (1837).

The German mathematician and physicist, Georg Friedrich von Parrot (1767-1852), was born in the Duchy of Württemberg. ${ }^{24}$ In 1802 he became professor of theoretical and experimental physics at the Imperial University of Dorpat (now Tartu in Estonia), and in 1826 was appointed head of the physics laboratory at the Academy of Sciences in St. Petersburg, Russia. An accomplished mountaineer, he carried out geological studies as well as geophysical 
investigations involving gravity and magnetism. In addition to geology, his book Grundriß der Physik der Erde und Geologie, zum Gebrauche für akademische Vorlesungen [Outline of the physics of the earth and geology, for use in academic lectures] (Parrot 1815) included discussion of the figure of the earth, gravity, magnetism, the atmosphere and seas. It was followed by a textbook by the Italian chemist and physicist Giuliano Giordano (1812-1878), a professor at the University of Naples. He too used the phrase 'physics of the earth' in its title and divided 'terrestrial physical phenomena' into six groups: thermal, atmospheric, aerodynamic, aqueous, electric, light (e.g. auroral manifestations) and volcanic, each of which was given lengthy treatment (Giordano 1858, pp. 260-466). Curiously, although he taught physics, it was his better-known colleague, the physicist and meteorologist Luigi Palmieri (1807-1896), credited with early development of the seismograph, who taught the course on 'Physics of the Earth' at the University (Scivoletto 1861, pp. 394-395).

The word geophysik appears in 1817 in a history of the University of Würzburg, Germany, which stated that 'geophysics (geogenie, physical geography, climatology and meteorology)' was being taught by the chemist and physicist Franz Lothar August Wilhelm Sorg (1773-1827), a native of that city (Goldmayer 1817). Sorg also taught theoretical and experimental physics and chemistry. Geophysik also occurred in a textbook on petrology (Naumann 1824 , p. 15) by the German mineralogist, mathematical crystallographer, and stratigrapher, Carl Friedrich Naumann (1797-1873), who was professor of physics in Kaliningrad from 1826. He founded a school of theoretical physics in 1834, where many of the investigations were essentially geophysical in nature (Kertz 1979).

A contemporary encyclopedia distinguished between 'geogenie' and 'geophysics or geography, whose purpose is to explain the changes in the landscape that are still present on the earth and in its atmosphere." ${ }^{25}$ The term occurred in a similar context in an article entitled Einiges zur Geophysik, oder besser Geophysiologie oder Geobiologie (zugleich enie kritik jetzt herrschender Ansichten in der Geologie) [Something about geophysics, or better geophysiology or geobiology (at the same time a critique of geology)], published in the scientific periodical Isis (Buquoy 1830) by the Czechoslovak natural scientist, philosopher and entrepreneur, Baron Georg Franz August de Lonueval, Freiherr von Buquoy (1781-1851).

At this time 'geophysics' appears to have been regarded as equivalent to 'physics of the earth', a term which Buntebarth (1981) suggests was used almost exclusively by physicists. He attributes the first use of geophysik to a German geographer at the University of Zürich, Carl Ferdinand Julius Fröbel (1805-1893) in the short-lived journal Mitteilungen aus dem Gebiete der Theoretischen Erdkunde [Communications from the field of theoretical geography], which Fröbel co-edited with the Swiss geologist and naturalist Oswald Heer (1809-1883), who was a lecturer in mineralogy. In the Foreword (dated February 1834), Fröbel explained that the journal was intended to cover: mathematical and general physical geography; general and special physical terrain ('orography' and hydrography) studies; geognosy and mineral geography; meteorology and climatology; plant geography; animal geography; and ethnography. The first issue opened with a lengthy essay by Fröbel on a "Draft of a system for geographical sciences" in which he mentions:

the science of geology in the broadest sense of the word, as a general natural science of the Earth (Earth physics; geophysics; theoretical geography); [emphasis as in original] (Fröbel 1834, p. 26). ${ }^{26}$

Under 'theory of the earth', Fröbel grouped gravity, chemical 'affinity', heat, light, electricity, magnetism and crystallization together as 'telluric processes'. Gravity was also included as a 'cosmic processes' (Fröbel 1834, pp. 124-125). However, apart from the quotation above, the word geophysics did not occur in his article again, but it is interesting that he clearly drew a distinction between 'geophysics' and 'physics of the earth.'

Kertz (1979) has suggested that in Germany, the works of Naumann, Humboldt, and Ferdinand Reich (1799-1882) were particularly influential in raising awareness of the new science of geophysics. Reich was professor of physics and lecturer on palaeontology at the Mining Academy in Freiberg. His geophysical investigations included studies of the variation on temperature with depth in mines, magnetism, torsion balance measurements of earth density, and the palaeomagnetism of basalts (Reich $1834 a, 1834 b, 1838,1849$ ).

Shortly after this, the German mineralogist, geologist and palaeontologist, Ernst Friedrich Glocker (1793-1858), a Professor at the University of Breslau, used a narrower definition of 'geophysics' in a serial publication Systematischer Bericht über die Fortschritte der Mineralogie [Systematic report on the progress of mineralogy] (1835-41), which was largely devoted to systematic mineralogy (Glocker 1837). Its contents list was as follows:

1. History of mineralogy

2. Latest literature on mineralogy

3. Crystallography

4. Mineral physics

5. Mineral chemistry

6. Special oryctognosy
7. Geognosy
A. Geology - Earth history
B. Geophysics
i Geothermal energy
ii Geoelectrical
C. General geognosy
D. Specific geognosy 
It is interesting that both geology and geophysics are included as subcategories of geognosy and that 'geophysics' is restricted to two topics (which we would today place in that subject area), namely: geothermy (he discusses the increase of temperature with depth within the earth, as observed in mines, and the lack of a relationship between subsurface and surface temperatures) and geoelectricity (he reports on electrical phenomena which had been observed in mines in Cornwall, England). Glocker used similar subdivisions in the first (1835) issue of the serial publication.

By this time, increasing numbers of books by leading scientists ${ }^{27}$ and articles in serial publications ${ }^{28}$, which were concerned with what would today be regarded as essentially geophysical topics, helped to raise the profile of geophysical (particularly geomagnetic) investigations.

In 1863, a German doctor, Adolf Mühry (1810-1888), who was interested in the connection between meteorology, climate and the spread of disease, published a book titled Beitraege zur Geo-physik und Klimatographie [Contributions to geo-physics and climatography]. However, he did not use the term 'geo-physik' elsewhere and his hyphenated spelling of the word does not seem to have been taken up by others.

More significantly, it was followed by the two-part Lehrbuch der Geophysik und physikalischen Geographie (1884-1885) [Manual of geophysics and physical geography] by the German mathematician, physicist and geographer, Adam Wilhelm Siegmund Günther (1848-1923), who was at that time professor of mathematics and physics at the Gymnasium in Ansbach. In 1886 he became professor of geography at the Technische Hochschule in Munich. In a lengthy introduction, he gave an extensive survey of views about geography and the gradual development of the study of physical geography from Antiquity to the eighteenth century. He noted that the science of terrestrial magnetism was pioneered by Christopher Hansteen (1784-1873) in Norway, and by Karl Friedrich Gauss (1777-1855) and Humboldt in Germany; terrestrial electricity by Benjamin Franklin (1706-1790) in America, and by Carl August von Steinheil (1801-1870) and Johann von Lamont (1805-1879) in Germany; and volcanic and seismic phenomena by George Julius Poulett Scrope (1797-1876) in England, Robert Mallet (1810-1881) in Ireland, Karl Albert Ludwig von Seebach (1839-1880) in Germany, Michele Stefano de Rossi (1834-1898) in Italy, and Eduard Suess (1831-1914) in Austria (Günther 1884-1885, I, p. 19). ${ }^{29}$ He went on to suggest that "in a narrow sense, the so-called geophysical school" was essentially British, beginning with the mathematician, geologist and seismologist William Hopkins (1793-1866) and subsequently involving the astronomers George Biddell Airy (1801-1892) and George Howard Darwin (1845-1912); the Irish mathematician and physicist, Sir George Gabriel Stokes (1819-1903); and the Irish-born physicist, Sir William Thomson (1824-1907); all of whom applied mathematical analysis to terrestrial phenomena, such as the nature of the earth-moon system, tides and hydrodynamics, geology, secular cooling of the earth, atmospheric electricity and electromagnetism. He concluded (Günther 1884-1885, I, p. 30) that 'geophysics (physics of the earth)' and 'physical geography' could not be conceptually separated and were essentially synonymous. ${ }^{30}$

The contents of his book embodied this view: The first part concerned the solar system, the earth's position within it and the earth-moon system. He then discussed the shape of the earth, gravitational attraction, the geoid, the rotation of the earth and methods of graphical depiction of the earth's surface, using projection methods and the use of isolines to depict land height and ocean depth. Finally, a section "Geophysics in the narrower sense" covered temperature variation with depth in mines, boreholes and tunnels, hypotheses about the interior of the earth, volcanic phenomena and earthquakes. His subsequent Handbuch der Geophysik (1897-1899) also held to this plan.

Figure 3 shows that while usage of the phrase 'physics of the Earth' has changed relatively little following its introduction, that of 'physical geography' increased steadily until the 1860 s, whereas use of 'geophysics' continued to increase from 1861 until about 1960 and that of 'geophysicist' increased steadily from 1877 into the twentieth century, reaching its peak in 1958 (Figure 4; partly accounted for by an increase in use in the Italian and Spanish literature) before showing a decline in modern times.

The relative frequencies of 'geophysicist' in the various languages (Figure 5) show that its take-up appears to have begun in Germany, Italy and France some 20-30 years before that in English-language publications. This is particularly striking when it is considered that the English-language Google n-gram corpus is over four times larger than that for the other languages. Note the continued increase in the English literature after the 1960s, whereas Italian, Spanish, German and French usage all begin to decline after that time.

The 1880s saw the emergence of the first serial publications dedicated to what we would now regard as 'geophysical' topics (Table 1, Figure 6). Many of these were the products of the growing number of observatories recording earth tremors, the first of which was established in Japan by the English geologist, engineer and seismologist, John Milne (1850-1913). He took up the position of Professor of Mining and Geology at the 

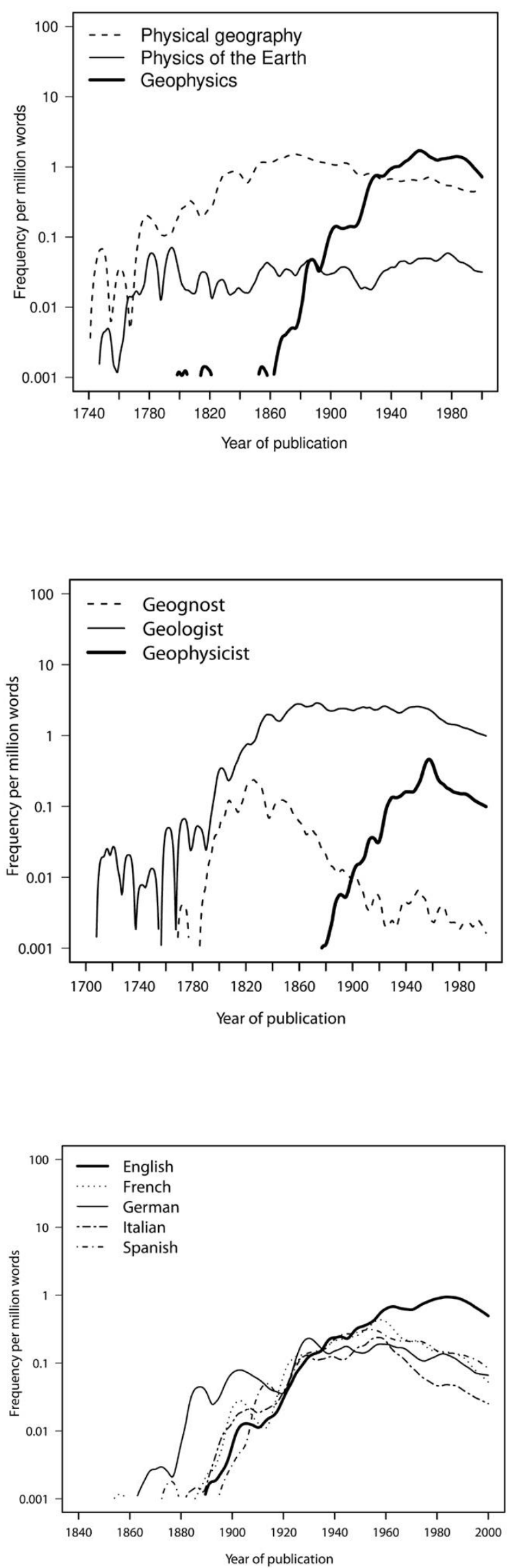

Figure 3. Relative annual frequency of the phrases 'physics of the Earth',

'physical geography', and 'geophysics (including their equivalents in French, German, Italian and Spanish) between 1740 and 2000 in the Google n-gram corpuses.

Figure 4. Relative annual frequency of the terms 'geognost, 'geologist' and 'geophysicist' (including their

equivalents in French, German, Italian and Spanish) between 1800 and 2000 in the Google n-gram corpuses.

Figure 5. Relative annual frequency of the word 'geophysicist' and its equivalents in English, French, German Italian and Spanish between 1840 and 2000 in the Google n-gram corpuses. 
Imperial College of Engineering in Tokyo in 1876. He had an active interest in volcanoes and, following the TokyoYokohama earthquake of February 1880, this broadened into the development of instruments for monitoring earthquakes (Milne 1898). Together with others, he founded the Seismological Society of Japan and the publication of the Transactions of this society marks the beginning of dedicated geophysical serials (see also Schweitzer and Lee 2003).

Table 1. Early geophysical serial publications

\begin{tabular}{|c|c|}
\hline Duration & Title \\
\hline 1880-1892 & Transactions of the Seismological Society of Japan (Tokyo) \\
\hline 1887-1990 & $\begin{array}{l}\text { Beiträge zur Geophysik [Contributions to geophysics] (Leipzig), subsequently known as Gerlands Beiträge zur } \\
\text { Geophysik }\end{array}$ \\
\hline 1887-1945 & $\begin{array}{l}\text { Tökyo-Teikoku-Daigaku-Rigakubu-kiyo [Journal of the College of Science, Imperial University of Tokyo] } \\
\text { (Tokyo) }\end{array}$ \\
\hline 1895-1930 & Bollettino della Società sismologica Italiana [Bulletin of the Italian Seismological Society] (Rome) \\
\hline $1897-1926$ & $\begin{array}{l}\text { Mitteilungen der Erdbeben-Commission der Kaiserlichen Akademie der Wissenschaften in Wien. } \\
\text { [Communications of the Earthquake Commission of the Imperial Academy of Sciences in Vienna] (Vienna) }\end{array}$ \\
\hline 1897-1930 & Publications of the Earthquake Investigation Committee in foreign languages (Tokyo) \\
\hline 1899-1948 & Terrestrial Magnetism and Atmospheric Electricity (Cincinnati, Ohio) \\
\hline 1900-1913 & Circular. Seismological Committee, British Association for the Advancement of Science (Newport) \\
\hline 1901-1913 & $\begin{array}{l}\text { Comptes Rendus des Seances de la Commission sismique permanente de Saint-Pétersbourg [Proceedings of the } \\
\text { Sessions of the Permanent Seismic Commission of St. Petersburg] (St. Petersberg) }\end{array}$ \\
\hline 1902-1913 & $\begin{array}{l}\text { Izvestiya Postornnoi Tsentral'noi Seismicheskoi Komissii. Imperatorskaya Akademiya Nauk [Proceedings of the } \\
\text { Postornoy Central Seismic Commission. Imperial Academy of Sciences] (St. Petersburg) }\end{array}$ \\
\hline 1907-1937 & $\begin{array}{l}\text { Publications du Bureau central de l'Associacion internationale de sismologie. Serie A. [Publications of the } \\
\text { Central Bureau of the International Association of Seismology] (Strassburg) }\end{array}$ \\
\hline 1918-1969 & International seismological summary (Edinburgh) \\
\hline 1921-1924 & Seismological Notes. Imperial Earthquake Investigation Committee (Tokyo) \\
\hline 1922-1934 & $\begin{array}{l}\text { Comptes rendus des seances de la Union Geodesique et Geophysique Internationale [Proceedings of the meetings } \\
\text { of the International Geodesic and Geophysical Union] (Toulouse) }\end{array}$ \\
\hline 1922-1947 & $\begin{array}{l}\text { Nihon tenmongaku oyobi chikyu butsurigaku shühō: gencho oyobi shoroku [Japanese journal of astronomy and } \\
\text { geophysics. Transactions and abstracts] (Tokyo) }\end{array}$ \\
\hline 1922-1957 & Geophysical supplements to the monthly notices of the Royal Astronomical Society (London) \\
\hline 1922-1960 & Transactions of the American Geophysical Union (Washington) \\
\hline 1922-1988 & Zeitschrift für angewandte Geophysik [Journal of applied geophysics] (Berlin) \\
\hline 1924-1944 & $\begin{array}{l}\text { Veröffentlichungen der Reichsanstalt für Erdbebenforschung in Jena [Publications of the German Empire } \\
\text { Institute for earthquake research] (Jena) }\end{array}$ \\
\hline 1924-current & Zeitschrift für Geophysik [Journal of geophysics] (Braunschweig) \\
\hline 1925-1927 & Izvestiya Instituta Prikladnoi Geofiziki [News of the Institute of Applied Geophysics] (Leningrad) \\
\hline 1925-1944 & $\begin{array}{l}\text { Tōkyō Daigaku Rigakubu kiyō. Dai 2-rui, Chishitsugaku, kōbutsugaku, chirigaku, jishingaku [Journal of the } \\
\text { Faculty of Science, University of Tokyo. Section 2. Geology, mineralogy, geography, geophysics] (Tokyo) }\end{array}$ \\
\hline & Geophysics (Tulsa) \\
\hline & eofisica Pura e Applicata [Pure and applied geophysics] (Milan) \\
\hline
\end{tabular}

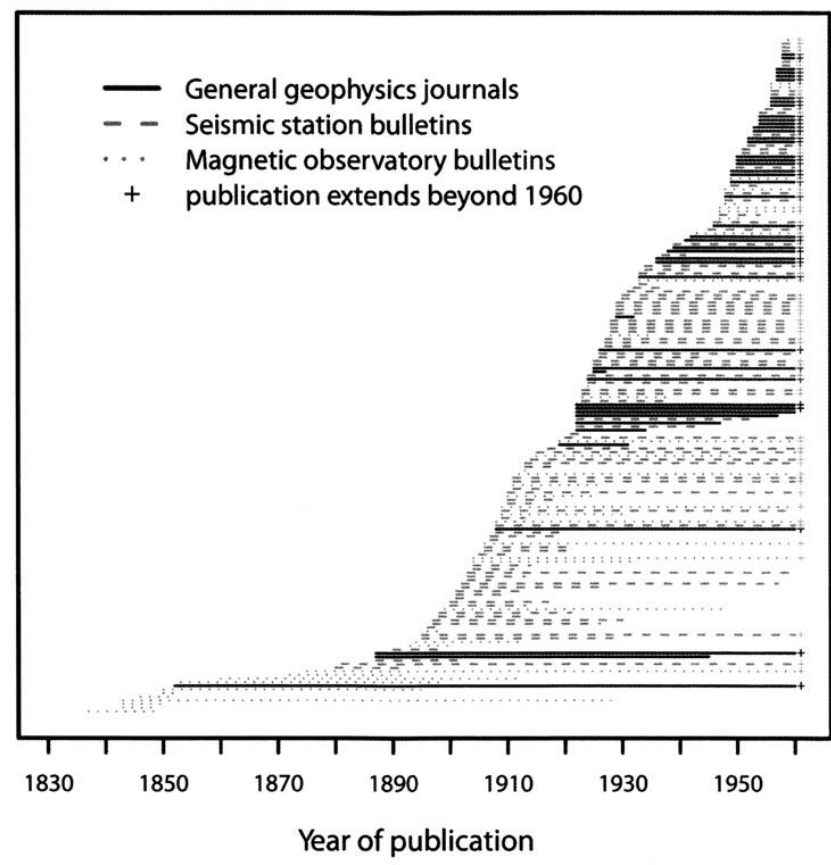

Figure 6. Timelines for 185 geophysical journals and other serial publications which began prior to 1960. 
What can now be regarded as the first general geophysical journal, Beiträge zur Geophysik [Contributions to geophysics], began publication in $1887 .{ }^{31}$ It was founded by the German philologist, anthropologist, geographer and, ultimately, geophysicist, Georg Karl Cornelius Gerland (1833-1919). He initially studied philology and anthropology in Berlin and Marburg, then taught in high schools in Kassel, Hanau, Magdebourg and Halle from 1856, until his appointment as Professor of geography and ethnology at the University of Strasbourg, France, in 1875, where he remained until his retirement in 1909. During that time, he lectured on theology, ethnology, cartography, mathematical and descriptive geography, biogeography and geophysics. Rejecting the established view that geography was the study of the surface of the earth because he believed that the surface could not be considered in isolation, he envisaged the subject as the study of the Earth in its totality, the result of interaction between interior and exterior forces: a complex of interactions which tended towards a stationary state. He regarded geography as a physical science, embodying the study of those interactions and the transformation of 'telluric' material as the result of their effect, whose basis was the 'physics of the globe'. Seismicity could be thought of as one manifestation of this interaction.

In 1887 Gerland established the Bureau Central Météorologique d'Alsace-Lorraine in Strasbourg, under the direction of his former pupil, the meteorologist Hugo Emil Hergesell (1859-1938), the Kaiserlichen Hauptstation für Erdbebenforschung zu Strassburg [Imperial main station for earthquake research at Strasbourg (KHES)] in 1900, and the Bureau Central International de Sismologie in 1901. Gerland undertook the roles of both director of the seismological station and editor of Beiträge zur Geophysik until 1909, when he retired as a result of his age and health (Vogt 1999). ${ }^{32}$ At the Sixth International Geographical Congress, held in London in 1895, Gerland, supported by his fellow-countryman the seismologist, Ernst von Rebeur Paschwitz (1861-1895), put forward the case for the establishment of an international seismological association and, at the following Congress, held in Strasbourg in 1901, the International Seismological Association was formally established, and completed its organization in 1903. As a consequence, from 1895 to 1918, the front cover of the Beiträge included the subtitle Zeitschrift für physikalische Erdkunde [Journal of physical geography], to which was added in 1908 Zugleich Organ der Kaiserlichen Hauptstation für Erdbebenforschung zu Strassburg [also the mouthpiece of the KHES], but in 1911 it was renamed G. Gerland's Beiträge zur Geophysik. Following suspension of publication between the years 1919 to 1925 , it resumed in 1926 as Gerlands Beiträge zur Geophysik, a title which it retained until it eventually ceased publication in 1990.

The earliest geophysical investigations were directed to unravelling the mysteries of 'physics of the Earth', embracing subjects such as the Earth's gravity and magnetic fields, seismicity related to earthquakes and volcanic activity, heat flow, geoelectricity and auroral displays, etc. However, as time went on, it was realised that geophysical methods could also be usefully applied to the search for minerals, oil and gas. Looking back over the initial period of growth in the geophysical literature from the perspective of the 1920s is made possible to some extent by means of the extensive bibliography in one of the first textbooks on applied geophysics, Methoden der angewandten Geophysik [Methods of applied geophysics], published by a leading German exponent of the science, Richard Karl Theodor Ambronn (1887-1954), in 1926 (English translation in Ambronn 1928). Ambronn began his own journal, Zeitschrift für angewandte Geophysik [Journal of applied geophysics] in 1922, which continued to the present day.

A frequency distribution of the years of publication of the works cited in Ambronn's bibliography (Figure 7) reflects steady growth in the field from 1870 onwards, apart from a brief downturn during the First World War. Taken together with the evidence of Figures 3-5, it suggests that geophysics really began as a discipline in the 1860s.

\section{EARTH SCIENCE AND GEOSCIENCE}

A definition of earth science in a 1990s encyclopedia reads: "earth science(s): dealing with the various aspects of the physical constitution of the earth, as geology, geophysics, oceanography, meteorology, etc." (Brown 1993, p. 775) but the word "geoscience" is not included in the dictionary. By way of contrast, a contemporary definition states that "earth science or geoscience includes all fields of natural science related to the planet Earth." These include: geology and subdivisions: environmental geology, Quaternary geology, planetary geology, petroleum geology, historical geology, hydro geology and structural geology, but also: geochemistry, geochronology, geomagnetics, geomicrobiology, geophysics, mineralogy, palaeontology, micropalaeontology and palynology, petrology, physical geodesy, sedimentology, seismology, stratigraphy and volcanology; but in addition: atmospheric science, geodesy, geography, glaciology, oceanography and planetary science. ${ }^{33}$ Nevertheless, use of the terms earth science and geoscience can be traced back to 1852 and 1929 respectively (Figure 8). There is not space to go into detail here, but early examples include the occurrence of la science de la terre in de Nigris (1851), Geowissenschaften in Richthofen (1862), earth-science in Wilson (1883), and geoscience in Field (1941). 

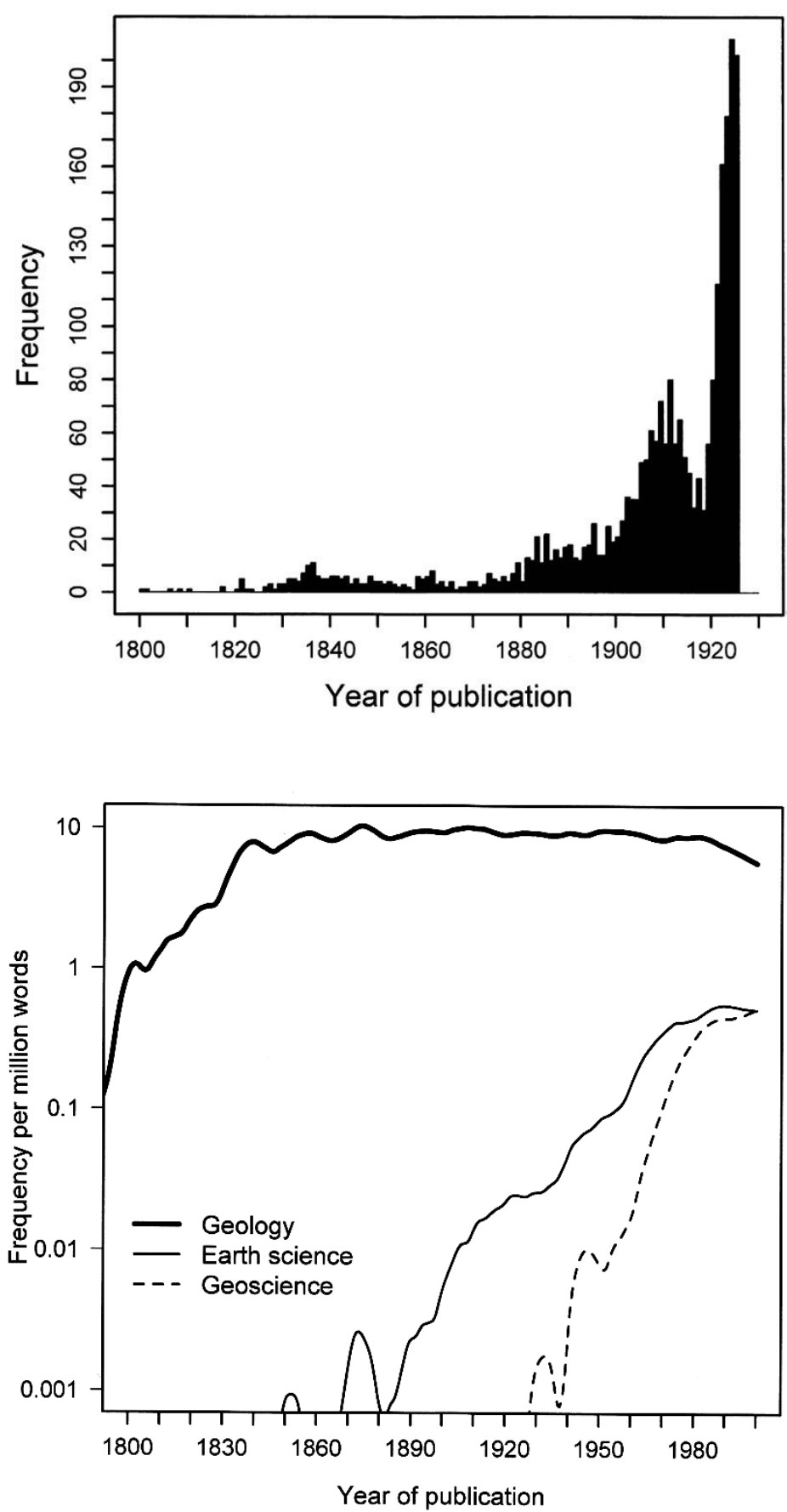

Figure 7. Frequency distribution of the year of publication of the 2475 works cited in the bibliography of Methoden der angewandten Geophysik (Ambronn 1926).
Figure 8. Relative annual frequency of the words 'geology,' 'earth science' and 'geoscience' (including their equivalents in French, German, Italian and Spanish) between 1800 and 2000 in the Google ngram corpuses..

\section{CONCLUSIONS}

Although there was some early criticism of the way the Google Books Ngram Corpus was compiled (e.g. Nunberg 2009), provided the data have been suitably normalized (Younes and Reips 2019; see f.n. 3 above), despite the exclusion of very low numbers of annual n-gram occurrences (which does not make it possible to identify the very earliest occurrence of a particular term in the corpus), graphs of the variation of normalized n-gram frequency through time have been found in this work to provide a useful aid to the study of the history of the geosciences. The timetrends summarised below are based on multi-lingual averages.

The idea that the word geologia was introduced by the Italian natural philosopher and mineral collector, Aldrovandi, in the late sixteenth century, rather than by the English cleric de Bury some 130 years earlier, is supported. The term entered the literature around 1700 and a major increase in its use, began in 1796 and lasted until about 1850, after which it remained levelled-off, although the exact meaning of the word geology changed during that time from 
an all-embracing 'philosophical View of the terraqueous Globe' to a more focussed 'account of all the stony masses which compose the crust of the earth.' Usage of geologist followed a similar path.

The terminology introduced in Germany by Füchsel and Werner, who were trying to discriminate between what was based on observation and established facts from speculative theory: geognosy (what was known of the nature of the Earth), geogony (theories regarding the formation of the Earth) and oryctognosy (the identification of minerals) entered the literature in 1768 and reached their maximum usage in 1819, 1824 and 1826 respectively, after which time they progressively fell out of use. Reference to their followers, geognosts, followed a similar pattern, also beginning to diminish after 1825 .

Following many years of observation of magnetic phenomena, gravity, and the occurrence of earthquakes (e.g. use of the term Physik der Erde goes back to the eighteenth century), the science of geophysics became properly established in the mid-nineteenth century and this was reflected in a steady growth of magnetic and seismic observatory bulletins after 1830. The term geophysicist began to appear in the German literature about 1860 and the first dedicated journal, Beiträge zur Geophysik, began publication in 1887.

Significant usage of our all-encompassing 'modern' terms earth science and geoscience began in 1852 and 1929 respectively.

\section{ACKNOWLEDGEMENTS}

I thank Hugh Torrens for his encouragement and the Editor for his eagle eye; most helpful comments were also provided by the referees: Celal Sengor, who drew my attention to West's translation of de Bury, and to Dean (1979) of which, embarassingly, I was unaware; and Gary Rosenberg who provided copious food for thought, as well as pointing me to the papers in Roseberg and Clary (2018).

\section{REFERENCES}

Adams, F.D. 1938. The Birth and Development of the Geological Sciences. Baltimore: Williams \& Wilkins.

Ambronn, R. 1926. Methoden der angewandten Geophysik. T. Steinkopff. Dresden.

Ambronn, R. 1928. Translated from German by M. Cobb. Elements of Geophysics as Applied to Explorations for Minerals, Oil and Gas. New York: McGraw-Hill.

Anonymous. 1697. Universa Philosophiae Institutio [book review]. Journal des Sçavans 24: 92-97.

Anonymous. 1765. History of a new Metal known by the name of White Gold or Platina; by Mess. Macquer and Baumé. Extracted from the memoirs of the Academy of Sciences at Paris, for the year 1758, published last year. The Annual Register, or a View of the History, Politics, and Literature for the Year 1764. 7: 199-123.

Anonymous. 1829. Wörterbuch der Naturgeschichte, dem gegenwärtigen Stande der Botanik, Mineralogie und Zoologie angemessen. Sechster Band. Gariofilata-Herinacěus. Weimar: Landes-Industrie-Comptoirs.

Anonymous. 1888. Beiträge zur Geophysik. Abhandlungen aus dem geograpischen Seminar der Universität Strassburg. Ed. G. Gerland. Vol. I. Stuttgart: Schweizerbart. Science. n.s. 11 (273): 203.

Avogadro, A. 1837. Fisica de' corpi ponderabili; ossia Trattato della costituzions general de' corpi. Tomo I. Turin: Stamperia Reale.

Bacon, F. 1620. Instauratio magna [Novum organum]. London: John Bill.

Bakewell, R. 1813. Introduction to Geology illustrative of the General Structure of the Earth, comprising the Elements of the Science, and an outline of the Geology and Mineral Geography of England. London: J. Harding.

Bakewell, R. 1828. An Introduction to Geology: comprising the Elements of the Science in its present advanced state and all the recent discoveries: with an outline of the Geology of England and Wales. London: Longman, Rees, Orme, Brown and Green.

Barraclough, D. R. 1985. Halley's Atlantic magnetic surveys. In: Historical Events and People in Geosciences, edited by W. Schroder, 163-183. Frankfurt-am-Main: Lang.

Brandt, D. S. 2018. Charting the Geosciences with Google Ngram Viewer. GSA Today, 28. doi: 10.1130/GSATG348GW.1.

Bromhead, C. E. N. 1945. Geology in Embryo (up to 1600 A.D.). Proceedings of the Geologists Association 61: 89-134.

Brown, L. (ed.) 1993. The New Shorter Oxford English Dictionary. Volume 1 A-M. Oxford: Clarendon Press.

Buntebarth, G. 1981. Zur Entwicklung des Begriffes Geophysik. Abhandlungen der Braunschweigischen Wissenschaftlichen Gesellschaft 32: 95-109.

Buquoy, G. F. A. von, 1830. Einiges zur Geophysik, oder besser Geophysiologie oder Geobiologie (zugleich enie kritik jetzt herrschender Ansichten in der Geologie. Isis 23 (12): cols. 1193-1199 [pp. 600-603].

Burnet, T. 1681. Telluris theoria sacra : Orbis Nostri Originem \& Mutationes Generales, quas Aut jam subiit, aut olim subiturus est, Complectens. Libri Duo Priores de Diluvio \& Paradiso. London: Walter Kettilby.

Burnet, T. 1684. The Theory of the Earth: Containing an Account of the Original of the Earth, and of All the General Changes which it hath already undergone, or is to undergo, Till the Consummation of all Things. The Two First Books Concerning the Deluge, and Concerning Paradise. London: Walter Kettilby.

Burnet, T. 1689. Telluris Theoria Sacra: Orbis Nostri Originem \& Mutationes Generales, quas Aut jam subiit, aut olim subiturus est, Complectens. Libri Duo Posteriores de Conflagratione Mundi, et de Futuro Rerum Statu. London: Walter Kettilby.

Burnet, T. 1690. The Theory of the Earth: Containing an Account of the Original of the Earth, and of all the General Changes Which it hath Already Undergone, or is to Undergo, Till the Consummation of all Things. The Two Last Books, Concerning the Burning of the World, and Concerning the New Heavens and New Earth. London: Walter Kettilby.

Cally, P. 1695. Universae philosophiae institutio. Caen: Joannem Cavelier. 2 vols. 
Cleveland, W. S. 1979. Robust locally weighted regression and smoothing scatterplots. Journal of the American Statistical Association 74: 829-836.

Clüver, D. 1700. Geologia; Sive, Philosophemata De Genesi Ac Structura Globi Terreni. Oder: Natürliche Wissenschaft, Von Erschaffung und Bereitung der Erd-Kugel, Wie nemlich Nach Mosis und der ältesten Philosophen Bericht Aus dem chao Durch Mechanische Gesetze der Bewegungen, die Erde sey herfür gebracht worden. Hamburg: G. Liebezeit.

de Bury, R. 1832. Philobiblon, A treatise on the love of books: by Richard de Bury, Bishop of Durham. Written in MCCCXLIV, and translated from the first edition, MCCCCLXXIII. With some collations. Translated, J.B. Inglis. London: T. Rodd.

de Bury, R. 1861. Philobiblon, a treatise on the love of books: by Richard de Bury, Bishop of Durham, and Lord Chancellor of England. First American Edition, with the literal English translation of John B. Inglis. Collated and corrected, with notes, by Samuel Hand. Albany: Joel Munsell.

de Bury, R. 1888. The Philobiblon of Richard de Bury, Bishop of Durham, Treasurer and Chancellor of Edward III. Edited and translated by Ernest $C$. Thomas. London. Kegan Paul, Trench.

de Bury, R. 1889. Ricardi de Bury Philobiblon ex optimis codicibus recensuit versione Anglica necron et prolegomenis adnotationibus auxit Andreas Fleming West [The Philobiblon of Richard de Bury: edited from the best manuscripts and translated into English with an introduction and notes by Andrew Fleming West]. New York: Grolier Club. [vol. 1, Latin text; vol. 2, English text; vol. 3, notes].

de Nigris, J.-B. 1851. Théorie du Temps qui Éléve l'Age de la Terre au-dela de 3 Millions d'Années a l'aide de la Géologie, de l'Astronomie \& des Monuments Mythologiques. Douai : Adam d'Aubers.

Dean, D. R. 1979. The Word 'Geology.' Annals of Science 36: 35-43.

Desmarest, N. 1757. Géographie. In: Encyclopédie ou Dictionnaire Raisonné des Sciences, des Arts et des Métiers, par une Societé de gens de lettres, edited by Diderot, D. and D'Alambert, J. le R. Paris: Briasson, David, Le Breton and Durand. 7: 608626.

Erman, E. 1835. Reise um die erde durch Nord-Asien und die beiden oceane in den jahren 1828, 1829 und 1830 ausgeführt: abth. Physikalische beobachtungen: Erster Band. Ortsbestimmungen und declinationsbeobachtungen auf dem festen lande. Berlin: G. Reimer.

Erman, E. 1841. Reise um die Erde durch Nord-Asien und die beiden Oceane: in den Jahren 1828, 1829 und 1830. Zweite Abtheilung: Physikalische Beobachtungen. Zweiter Band. Inclinationen und Intensitäten. - Declinationsbeobachtungen auf der See. - Periodische Declinationsveränderungen. Berlin: G. Reimer.

Escholt, M. P. 1663. Geologia Norvegica. Or, a brief instructive Remembrancer, Concerning that very great and spacious Earthquake, Which hapned almost quite through the South parts of Norway: Upon the $24^{\text {th }}$. Day of April, in the year 1657. Also Physical, Historical, and Theological Grounds and Reasons concerning the causes and significations of Earthquakes. Written in the Danish Tongue, by Michael Peterson Escholt, sometimes Minister of Ackers-house Castle in Norway. And Englished by Daniel Collins. London: S. Thomson.

Evenhuis, N. L. 2015. Dating, publication, and authorship of Froriep's "Wörterbuch der Naturgeschichte" (1824-1837). Bishop Museum Bulletin in Zoology 9: 49-58.

Fantuzzi, G. 1774. Memorie della vita di Ulisse Aldrovandi medico e filosofo Bolognese, Con alcune Lettere scelte d'Uomini eruditi a lui scritte, e coll'Indice delle sue Opere Mss., che si conservano nella Biblioteca dell' Istituto. Dedicate Algi Erud.mi Accademici dell'Istituto di Bologna. Bologna: Lelio dalla Volpe.

Field, R.M. 1941. Geophysics and world affairs: A plea for geoscience. Eos 22: 255-234.

Fröbel, J. 1834. Entwurf eines Systemes der geographischen Wissenschaften. Mitteilungen aus dem Gebiete der Theoretischen Erdkunde 1(1): 1-99; (2): 121-132.

Füchsel, G. C. 1761. Historia terrae et maris: ex historia Thuringiae, per montium descriptionem erecta. Acta Academiae Electoralis Morguntinae zu Efurt 2: 44-209.

Gale, T. 1672. The Court of the Gentiles: or a Discourse touching the Original of Human Literature, Both Philologie and Philosophie, from the Scriptures and Jewish Church. Oxford: T. Gilbert.

Gauss, C. F. 1839. Allegemeine Theorie des Erdmagnetisismus. In: Resultate aus dem Beobachtungen des magnetischen Vereins in Jahre 1839, by C. F. Gauss and W. Weber, 1836-1841, 1-57. Göttingen: Dieterich.

Gauss, C. F. 1841. Translated from German by E. J. Sabine; J. Herschel (ed.). General theory of terrestrial magnetism. In: Scientific Memoirs selected from the Transactions of Foreign Academies of Science and Learned Societies, and from Foreign Journals, edited by Richard Taylor, 2: 184-243. London: R. and J.E. Taylor.

Geikie, A. 1879. Geology. In: The Encyclopaedia Britannica a Dictionary of Arts, Sciences, and General Literature. Ninth Edition. Volume X. 212-375. Edinburgh: Adam and Charles Black.

Geikie, A. 1902. Geology. In: The New Volumes of the Encyclopaedia Britannica constituting in combination with the existing volumes of the ninth edition the Tenth Edition of that work, a new, distinctive, and independent library of reference dealing with recent events and developments, edited by D. M. Wallace, A. T. Hadley, and H. Chisholm, 27: 633-658. Edinburgh: Black.

Gilbert, G. 1600. De magnete, magnetisque corporibus, et de magno magnete tellure; Physiologia nova, plurimis \& argumentis, \& experimentis demonstrata. London: P. Short.

Gilbert, G. 1893. Translated from Latin, P. F. Mottelay. William Gilbert of Colchester, Physician of London, on the Loadstone and Magnetioc Bodies, and on the great magnet of the Earth. A new physiology, demonstrated with many arguments and experiments. London: Bernard Quaritch.

Giordano, G. 1858. Trattato Elementare di Fisica Sperimentale e di Fisica Terrestre. Volume Primo. Naples: Frederico Vitale.

Glassmeier, K.-H. and Tsurutani, B. T. 2014. Carl Friedrich Gauss-General Theory of Terrestrial Magnetism-a revised translation of the German text. History of Geo- and Space Sciences 5: 11-62. 
Glocker, E. F. 1837. Systematischer Bericht über die Fortschritte der Mineralogie im Jahr 1835: Mit Berücksichtigung der Geologie und Petrefactenkunde. Nürnberg: Johann Leonhard Schrag.

Glocker, E.F. 1839. Grundriß der Mineralogie mit Einschuß der Geognosie und Petrefactenkunde. Nürnberg: Johann Leonhard Schrag.

Goldmayer, J. C. 1817. Beyträge zur neuesten Geschichte der Königlichen Universität zu Würzburg und der Berichtigung öffentlicher Nachrichten und Urtheile über dieselbe. Studienjahr 1816/1817. Würzburg: Franz Ernst Nitribitt.

Guntau, M. 2009.The rise of geology as a science in Germany around 1800. In: The Making of the Geological Society of London, edited by C. L. E. Lewis and S. J. Knell, 163-177. Geological Society Special Publication no. 317. London: The Geological Society.

Günther, S. 1884-1885. Lehrbuch der Geophysik und physikalischen Geographie. Stuttgart: Ferdinand Enke. 2 vols.

Günther, S. 1897-1899. Handbuch der Geophysik. Stuttgart: Ferdinand Enke. 2 vols.

Hansteen, C. 1819. Translated from Norwegian, by P. T. Hanson. Untersuchungen über den Magnetismus der Erde. Erster Thiel. Die mechanischen Erscheinungen des Magneten. Christiania: J. Lehman and C. Gröndahl.

Humboldt, A. von. 1823a. Essai Géognostique sue le Gisement des Roches dans les deux Hémispheres. Paris: F. G. Levrault.

Humboldt, A. von. 1823b. A Geognostical Essay on the Superposition of Rocks, in both Hemispheres. London: Longman, Hurst, Rees, Orme, Brown, and Green.

Humboldt, A. von. 1845-1862. Kosmos - Entwurf einer physischen Weltbeschreibung. Stuttgart: Cotta. 4 vols.

Humboldt, A. von. 1855-1858. Translated from German, by E. J. Sabine. Cosmos. Sketch of a Physical Description of the Universe. London: Longman, Brown, Green and Longmans. 4 vols.

Humboldt, A. von. 1868. Translated from German, E. C. Otté and B. H. Paul. Cosmos: A sketch of a Physical Description of the Universe. Vol. IV. New York: Harper and Bros.

Hunt, R. (ed.) 1860. Ure's Dictionary of Arts, Manufactures, and Mines containing a clear exposition of their principles and practice. London: Longman, Green, Longman, and Roberts.

Hutton, J. 1795. Theory of the Earth, with proofs and illustrations. In four parts. London: Cadell Jr. and Davies.

Jameson, R. 1830. Mineralogy. In: The Edinburgh Encyclopaedia, edited by D. Brewster, 14: 389-572. Edinburgh: William Blackwood and John Waugh.

Kertz, W. 1979. Die Entwicklung der Geophysik zur eigenständigen Wissenschaft. Gauss-Gesellschaft E.V. Göttingen Mitteilungen Nr. 16: 41-54.

Kidd, J. 1835. Catalogue of the works in Medicine and Natural History contained in the Radcliffe Library. Oxford: S. Collingwood.

Kircher, A. 1667. China monumentis, qua Sacris qua Profanis, Nec non variis Naturae \& Artis spectaculis, Aliarumque rerum memorabilium Argumentis Illustrata. Amsterdam: Jacob à Meurs.

Kircher, A. 1986. Translated from Latin, by C. D. Van Tuyl. China Illustrata. Muskogee, OK: Indiana University Press.

Klemun, M. 2018. Different functions of learning and knowledge - Geology takes form: Museums in the Hapsburg Empire, 18151848. In: Museums at the Forefront of the History and Philosophy of geology: History Made, History in the Making, edited by G. D. Rosenberg and R. M. Clary. 163-175. Special Paper 535. New York: The Geological Society of America.

Koeberl, C., Brandstätter, F., Harzhauser, M., and Riedl-Dorn, C. 2018. History and importance of the geoscience collections at the Natural History Museum Vienna In: Museums at the Forefront of the History and Philosophy of geology: History Made, History in the Making, edited by G. D. Rosenberg and R. M. Clary. 131-161. Special Paper 535. New York: The Geological Society of America.

Launay, G. de. 1667. Les essais physiques du Sr de Launay. Paris: C. Barbin.

Lin, Y., Michel, J. B., Aiden, E. L., Orwant, J., Brockman, W. and Petrov, S. 2012. Syntactic annotations for the Google Books Ngram corpus. In: Proceedings of the 50th Annual Meeting of the Association for Computational Linguistics, edited by M. Osborne, C.-Y. Lin, and H. Li, 169-174. Red Hook, NY: Curran Associates.

Lovell, R. 1661a. ПАNZQОРҮКТОАОГІА. . Sive, Panzoologicomineralogia. Or, a Compleat History Of Animals and Minerals, Containing the Summe of all Authors, both Ancient and Modern, Galenicall and Chymicall, touching Animals, viz. Beasts, Birds, Fishes, Serpents, Insetts, and Man, as to their Place, Meat, Name, Temperature, Vertues, Use in Meat and Medicine, Description, Kinds, Generation, Sympathie, Antipathie, Diseases, Cures, Hurts, and Remedies \&c. With the Anatomy of Man, his Diseases, with their Definitions, Causes, Signes, Cures, Remedies: and use of the London Dispensatory, with their Doses and Formes of all kinds of Remedies:also a History of Minerals, viz. Earths, Mettals, Semi-metals, with their Naturall and Artificiall excrements, Salts, Sulphurs, and Stones with their Place, Matter, Names, Kinds, Temperature, Vertues, Use, Choice, Dose, Danger and Antidotes. Also an \{Introduction to Zoography and Mineralogy. Index of Latine Names, with their English Names. Universall Index of Use and Vertues. Oxford: Joseph Godwin.

Lovell, R. 1661b. ПАNОРУКУОАОГІА. Sive Pammineralogicon. Or An Universal History Of Mineralls Containing the summe of all Authors, both Ancient and Moderne, Galenical and Chymical, touching Earths, Mettals, Semimettals, with their natural and artificial excrements, Salts, Sulphurs, and Stones, more pretious and lesse pretious \&c. Shewing their Place, Matter, Names, Kinds, Temperature, Vertues, Choice, Use, Dose, Danger, and Antidotes. Oxford: Joseph Godwin.

Luc, J. A. de. 1792. Vingtième lettre de M. de Luc a M. Delamétherie. Sur un commencement assignable des Phénomènes physiques observés à la surface de notre Globe, \& sur la cause de l'état actuel de nos Couches. In: Rozier, J.-B. F., Mongez, J.A. \& Delamétherie, J.-C. (eds.). Observations sur la physique, sur l'histoire naturelle et sur les arts. Paris: Bureau du Journal de Physique. 40: 180-197.

Martin, B. J. 1735. The Philosophical Grammar; Being a View of the Present State of Experimented Physiology, or Natural Philosophy. In four Parts. London: J. Noon.

Massuet, P. 1752. Elemens de la Philosophie Moderne, qui contiennent La Pneumatique, La Metaphysique, La Physique experimentale, Le Systeme du Monde, Suivant les nouvelles decouvertes. Tome premier. Amsterdam: Z. Chatelain et fils.

Michel, J.-B., Shen, Y. K., Aiden, A. P., Veres, A., Gray, M. K., The Google Books Team, Pickett, J. P., Hoiberg, D., Clancy, D., Norvig, P., Orwant, J., Pinker, S., Nowak, M. A., and Aiden, E. L. 2011. Quantitative analysis of culture using millions of digitized books. Science 331: 176-182.

Milne, J. 1898. Seismology. London: Kegan Paul, Trench and Trübner. 
Mühry, A. 1863. Beitraege zur Geo-physik und Klimatographie. Leipzig: C. F. Winter. 3 vols.

Naumann, C. F. 1824. Andeutungen zu einez Gesteins-Lehre, zunächt in Bezung auf die krystallinische Kieselreihe. Leipzig: Adolph Wienbrack.

Nunberg, G. 2009. Google's book search: A disaster for scholars. The Chronicle of Higher Education. http://www.chronicle.com/article/Googles-Book-Search-A/48245/.

Occhi, D. (ed.). 1757. Novelle della Repubblica Letteraria per l'anno MDCCXLVII. Venice: Giambattista Albrizzi.

Parrot, G. F. von. 1815. Grundriß der Physik der Erde und Geologie, zum Gebrauche für akademische Vorlesungen. Riga: Friedrich Meinshaufen.

Paulian, A.-H. 1761. Dictionnaire de Physique, dédié a Monseigneur le Duc de Berry. Tome troisiéme. Avignon: Louis Chambeau.

Paulian, A.-H. 1769. Systême Général de Philosophie extrait des ouvrages de Descartes et de Newton: Ouvrage. Dans lequel, après avoir rapporté les particularités les plus intéressantes des Vies de ces deux Chefs de la Physique Moderne, on examine leurs Découvertes en tout genre, \& on en montre l'analogie. Tome Premier. Avignon: La veuve Girard et François Seguin.

Paulian, A.-H. 1770. Dictionnaire Philosopho-Théologique Portatif. Nimes: Gaude.

Pechenick, E. A., Danforth, C. M. and Dodds, P. S. 2015. Characterizing the Google Books Corpus: Strong Limits to Inferences of Socio-Cultural and Linguistic Evolution. PLoS ONE. 10 (10): e0137041. https://doi.org/10.1371/journal.pone.0137041. $24 \mathrm{pp}$.

Pilla, N. 1823. Geologia Volcanica della Campania. Parte II. Storia fisica della Campania. Naples: Stamperia Reale.

Pott, J. H. 1746. Chymische Untersuchungen welche fürnehmlich von der Lithogeognosia, oder, Erkäntniss und Bearbeitung der gemeinen einfacheren Steine und Erden ingleichen von Feuer und Licht handeln. Potsdam: Christian Friedrich Voss.

Pott, J. H. 1753. Lithogéognosie ou Examen Chiymique des Pierres et des Terres en Général, Et du Talc, de la Topaze \& de la Stéatite en particulier, Avec und Dissertation sue le Feu \& sur la Lumiere. Paris: Jean-Thomas Herissant.

Régis, P.-S. 1691. Cours Entier de Philosophie, ou Système Général selon les principes de M. Descartes, contenant la logique, la métaphysique, la physique, et la morale. Tome Second. Amsterdam: Huguetan.

Reich, F. 1834a. Beobachtungern über die Temperatur des Gesteins in verschicdenen Tiefen in den Gruben des Sächsischen Erzgebirges in den Jahren 1830 bis 1832: nebst zwei Beilagen: I. Ueber die. Churprinzer lauwarme Quelle. II. Ueber das perennirende Eis im Sauberge. Freiberg: J.G. Engelhardt.

Reich, F. 1834b. Ueber die magnetische Neigung zu Freiberg (N.B. 50 55', O.L. 310'). Annalen der Physik und Chemie 31: 199-203.

Reich, F. 1838. Versuche über die mittlere Dichtigkeit der Erde: mittelst der Drehwage. Freiberg: J. G. Engelhardt.

Reich, F. 1849. Beobachtungen über die magnetische Polarität des Pöhlberges bei Annaberg. Annalen der Physik 153: $32-43$.

Reuss, F. A. 1798. Neues mineralogisches Wörterbuch, oder Verzeichniss aller Wörter, welche auf Oryctognosie und Geognosie Bezug haben mit Angabe ihrer wahren Bedeutung nach des Herrn Berg-Commissions-Rath Werners neuester Nomenclatur in alphabetischer Ordnung in Deutscher, Lateinischer, Französischer, Italienischer, Schwedischer, Dänischer, Englischer, Russischer und Ungarischer Sprache ; nebst einer tabellarischen Uebersicht der mineralogisch einfachen und gemengten Fossilien. Dictionnaire De Mineralogie contenant tous les mots en allemand, latin, français, italien, suédois, danois, russe et hongrois rélatifs à l'oryctognosie et à la géognosie. Hof: G.A. Grau.

Richthofen, F. F. V., 1862. Ueber das Vorkommen von Heinrich Edmund Naumann und die Entwicklung der Geowissenschaften in Tapan Nummulitenformation auf Japan und den Philippinen. Zeitschrift der deutschen geologischen Gesellschaft 14: 357-360.

Rosenberg, G. D. and R. M. Clary (eds.). 2018. Museums at the Forefront of the History and Philosophy of geology: History Made, History in the Making. Special Paper 535. New York: The Geological Society of America.

Sabine, E. 1838. Report on the variations of the magnetic intensity observed at different points of the earth's surface. Seventh Report of the British Association for the Advancement of Science. London: British Association for the Advancement of Science.

Sabine, E. 1840. Contributions to Terrestrial Magnetism. Philosophical Transactions of the Royal Society, London 130: 129-155.

Sabine, E. 1841. Contributions to Terrestrial Magnetism. No. II. Philosophical Transactions of the Royal Society, London 131: $11-35$.

Sabine, E. 1842. Contributions to Terrestrial Magnetism. No. III. Philosophical Transactions of the Royal Society, London. 132, 9-41.

Sabine, E. 1843a. Contributions to Terrestrial Magnetism. No. IV. Philosophical Transactions of the Royal Society, London 133: $113-143$.

Sabine, E. 1843b. Contributions to Terrestrial Magnetism. No. V. Philosophical Transactions of the Royal Society, London. 133, $145-231$.

Sabine, E. 1843c. Observations on days of Unusual Magnetic Disturbance, made at the British Colonial Magnetic Observatories, under the departments of the Ordnance and Admiralty. Part I. 1840-41. London: Longman, Brown, Green and Longmans.

Sabine, E. 1844. Contributions to Terrestrial Magnetism. No. VI. Philosophical Transactions of the Royal Society, London 134: $87-224$.

Sabine, E. 1846a. Contributions to Terrestrial Magnetism. No. VII. Philosophical Transactions of the Royal Society, London 136: 237-336.

Sabine, E. 1846b. Contributions to Terrestrial Magnetism. No. VIII. Philosophical Transactions of the Royal Society, London. $136,337-342$.

Sabine, E. 1849. Contributions to Terrestrial Magnetism. No. IX. Philosophical Transactions of the Royal Society, London 139: $173-234$. 
Sabine, E. 1851. Observations on days of Unusual Magnetic Disturbance, made at the British Colonial Magnetic Observatories, under the departments of the Ordnance and Admiralty. Volume I. Part I. 1840-41. Part II - 1842, 1843, 1844. London: Longman, Brown, Green and Longmans.

Sack, F. W. 1785. Geologie oder Betrachtung der Erde. Breslau: W. G. Korn.

Schmidt. J. C. E. 1829. Lehrbuch der mathematischen und physischen Geographie. Erster Theil. Mathematische Geographie. Göttingen: Vandenhoek and Ruprecht.

Schmidt. J. C. E. 1830. Lehrbuch der mathematischen und physischen Geographie. Zweiter Theil. Physische Geographie. Göttingen: Vandenhoek and Ruprecht.

Schweitzer, J., and Lee, W. H. K. 2003. Old Seismic Bulletins to 1920: A Collective Heritage from Early Seismologists. In: International Handbook of Earthquake and Engineering Seismology, edited by W. H. K. Lee, H. Kanamori, P. C. Jennings, and C. Kisslinger, et al. 81B: 1665-1723.

Schmidt, C. F. 1986. Whatever has happened to the semilogarithmic chart? The American Statistician 40: 238-244.

Scivoletto, P. 1861. Della Università di Napoli e dell'insegnamento delle scienze naturali in essa. Rivista Contemporanea 27: 393 405.

Smith, W. 1815. A Delineation of the Strata of England and Wales, with part of Scotland; exhibiting the collieries and mines, the marshes and fen lands originally overflowed by the sea, and the varieties of soil according to the variations in the substrata, illustrated by the most descriptive names. London: J. Cary.

Tessier, A. H., Thouin, A., and Fougeroux de Bondaroy, A-D. 1796. Géologie. In: Encyclopédie méthodique, ou par ordre des matières: Par une société de gens de lettres, de savans et d'artistes, edited by C.-J. Panckoucke, H. Agasse, and T. C. Agasse, 4[Agriculture]: 546-547. Paris: H. Agasse.

Thomson, T. 1812. History of the Royal Society, from its institution to the end of the eighteenth century. London: R. Baldwin.

Thrower, N. J. W. 1978. Edmond Halley and thematic geocartography. In: The Compleat Plattmaker, edited by N. J. W. Thrower, 195-228. Berkeley: University of California Press.

Thrower, N. J. W. (ed.) 1981. The three voyages of Edmond Halley in the Paramore, 1698-1701. Works issued by the Hakluyt Society, ser. 2, nos. 156-7. 2 vols. London: Hakluyt Society.

Vai, G. B. 2003. Aldrovandi's will: Introducing the term 'Geology' in 1603. In: Four Centuries of the Word 'Geology': Ulisse Aldrovandi 1603 in Bologna, edited by G. B. Vai and W. Cavazza, 64-111. Bologna: Minerva Edizioni.

Vai, G. B., and Cavazza, W. 2006. Ulisse Aldrovandi and the origin of geology and science. In: The Origin of Geology in Italy, edited by G. B. Vai and W. G. E. Caldwell, 43-63. Boulder, Colorado: The Geological Society of America.

Verulamio, F. de 1620. Instauratio magna. London: J. Bill.

Vogt, H. 1999. Les géographes à l'Université de Strasbourg pendant la période du Reichsland. Revue Géographique de l'Est. 39(1), 12 pp. Online: http://journals.openedition.org/rge/4520.

Wallace, R. (ed.) 1872-1875. The Popular Educator: A Complete Encyclopaedia of Elementary, Advanced, and Technical Education. New and Revised Edition. London: Cassell, Petter and Galpin. 6 vols.

Warren, E. 1690. Geologia: or, a Discourse Concerning the Earth before the Deluge. Wherein The form and Properties ascribed to it, In a Book intituled The Theory of the Earth, Are Excepted against: And it is made appear, That the Dissolution of that Earth was not the Cause of the Universal Flood. Also A New Explication of that Flood is attempted. Ecclesiast. lii. II. Et Mundum tradidit Disputationi eorum. London: R. Chiswell.

Werner, A. G. 1774. Von den äusserlichen Kennzeichen der Fossilen. Leipzig: S. Lebrecht.

Werner, A. G. 1791a. Neue Theorie von der Entstehung der Gänge, mit Anwendung auf den Bergbau. Freiberg: Gerlach.

Werner, A. G. 1791b. Ausführliches und systematisches Verzeichnis des Mineralien-Kabinets des weiland kurfürstlich sächsischen Berghauptmans Herrn Karl Eugen Pabst von Ohain, der Leipziger und St. Petersburger ökonomischen Gesellschaft Mitgliede, und der königlich sardinischen Gesellschaft der Wissenschaften zu Turin. Erster Band. Freiberg: Craz.

Werner, A. G. 1792. Oryktognosie, oder, Handbuch fur die Liebhaber der Mineralogie : vermittelst welchem die Mineralien aus ihrer äusserlichen Beschaffenheit leicht zu erkennen, von einander zu unterscheiden, und anderen kenntlich zu machen sind. Leipzig: S.L. Crusius.

Werner, A. G. 1805. Translated from German by T. Weaver. A Treatise on the External Characters of Fossils. Dublin: Longman, Rees, Hurst \& Orme.

Wilson, A. 1883. Facts and Fictions of Zoology. In: The World's Cyclopedia of Science. vol. 1, 207-272. New York: J.B. Alden. Woodward, H. B. 1908. The History of the Geological Society of London. London: Longmans, Green.

Younes, N., and Reips, U.-D. 2019. Guideline for improving the reliability of Google Ngram studies: Evidence from religious terms. PLoS ONE 14(3): e0213554. https://doi.org/10.1371/ journal.pone.0213554.

This term refers to the degree of flattening of the earth, regarded as an oblate ellipsoid.

This contains data from 8.12 million books, dating from 1500 to 2000. It comprises 4.54 million volumes in English; $0.79 \mathrm{M}$ in French; 0.85M in Spanish; 0.66M in German; 0.59M in Russian; 0.31M in Italian; 0.30M in Chinese; and 0.7M in Hebrew (Lin et al. 2012). Some of the 'books' are in fact bound volumes of journals.

3 The annual n-gram data were retrieved (ignoring case) from the various 2012 corpuses using Sean Carmody's ngramr package (https://github.com/seancarmody/ngramr, 2015) for the open-source $R$ language developed under the $R$-project for Statistical Computing (see: http://www.r-project.org/). However, n-grams occurring less than 40 times in the corpus are not recorded in the publicly-available database (Michel et al. 2011). In order to take account of variation between the differing language corpuses, the raw data trend for each n-gram was first normalised relative to the average frequency of occurrence of a set of 'neutral' words (i.e. 'words with little or no specific meaning'): the, of, and, in, a, is, was, not and other, in English and their equivalents in the other languages, as advocated by Younes and Reips (2019). The general timetrend for a given n-gram was then obtained by first averaging the normalised relative frequencies for each year across all 
corpuses used, and then smoothing the resulting average trend using robust locally-weighted regression (Cleveland 1979) with a 12-year moving window. This technique has been used to construct all the n-gram based figures in this paper. On account of the large variation in the frequency ranges of different $n$-grams, the results are displayed using semi-logarithmic charts. The advantages shown by this type of graph are discussed by Schmidt (1986): notably, an exponential increase or decrease becomes linear in a semi-logarithmic plot, which can cover a very wide range of values. Changes in the meaning of words cannot be taken into account. The Russian corpus has not been used here, as the average variation with time shown by some of the 'neutral' words was found to be very different between 1915 and 1925 to their relatively constant frequency in the other languages, and the reason for this is not clear.

4 Although the total sizes of each national corpus in the n-gram database are reported in Lin et al. (2012), the sample sizes per decade are not given. However, some data are available from the Hathi Trust Digital Library website in which the Google-scanned 'books' are deposited; see: https://www.hathitrust.org/visualizations_dates. Social science users of the database have suggested that it is biased towards science and engineering (e.g. Pechenick et al. 2015), but that is not a difficulty in this study.

$5 \quad$ These first two volumes appear always to have been printed as one.

$6 \quad$ Koeberl (2018) and Klemun (2018) discuss two major collections from the $18^{\text {th }}$ and $19^{\text {th }}$ centuries. Bromhead (1945) is informative on geological investigators before 1600, suggesting that "by the opening of the seventeenth century in England and Wales, France, Germany and Italy the infant science of Geology had come to birth" (p. 129).

7 This term, meaning a magnifying-glass (Latin: speculum comburens), occurs earlier in the first (Latin) edition of Sir Francis Bacon's (1561-1626) Novum Organum Scientarum [New Instrument of Science] (1620) e.g. item 28 of his Tabula Gradum, sive Comparativae in Calido [Table of Degrees, or Comparison in Heat; pp. 189-203] begins: 'Fiat Experimentum per specula comburentia ...' [Let a trial be made with burning glasses ...] (Verulamio 1620, p. 198). A similarly broad view of the scope of 'geology' was reflected in works by the German mathematician, astronomer and philosopher, Detlev Clüver (1645-1708) and by the theologian August Friedrich Wilhelm Sack (1703-1786) (Clüver 1700; Sack 1785).

$9 \quad$ Edmond (also spelled Edmund) Halley (1656-1742)

10 Known from antiquity; according to Gilbert (1600, p. 9) a loadstone (also spelt lodestone and load-stone; loadstone became the most common spelling after 1700) 'resembles unpolished iron and usually is found in iron mines' (English translation: Gilbert 1893, p. 18), its magnetic property being its notable feature. The earliest-known specimens were composed of ironore rich in magnetite which had become naturally magnetized as a result of lightning strikes on surface outcrops. Abraham Gottlob Werner (1749-1817)

Oryktognosie occurs in the title of Werner (1792); and both oryctognosie and geognosie in the title of a multilingual dictionary (Reuss 1798) of the terms used in Werner's mineral classifcation scheme; for an English version of the scheme itself see Jameson (1830, vol. XIV, pp. 389-572).

Guntau (2009, p. 169) gives these English translations as they appear in vol. 10, pp. 68-70, of the 84 volumes of of Werner's handwritten papers in the Georgius Agricola Library of the Technische Universität Bergakademie, Freiberg. See also Werner (1791b, p. xiv; 1805, pp. 1-2; 1792), Reuss (1798). Weaver's translation (Werner 1805) implies that Werner used the term oryctognosy in his 1774 German text, but he does not appear to have done so. Use of the term (in French) by Pott, is mentioned in Anonymous (1765, p. 120), where it is translated into English as lithogeognosy.

Very probably undertaken by Elizabeth Juliana Leeves (1807-1879), wife of the soldier and geophysicist Sir Edward Sabine (1788-1883); she later translated other works by Humboldt into English.

16 The English agriculturalist and geologist Robert Bakewell (1767-1843) was scathing regarding Werner's terminology: "Geognosy, as defined by Mr. Jameson, "teaches us the relative position and mode of formation of the mineral masses, of which the crust of the earth is composed." Though the Germans, who delight in multiplying words, affect to make a distinction between geology and geognosy, according to this definition they are synonymous.' 'The term "well educated geognost" as used by some writers denotes a perfect disciple of Werner, who lost the use of his own eyes by constantly looking through the eyes of his master [?Füchsel].' (Bakewell 1813, p. 353) Again: 'Werner and his disciples, and also some of the French geologists, have changed the term [geology] into Geognosy; but for this change no sufficient reason can be assigned', 'Nothing can be more unmeaning than the apologies that have been offered for substituting $\gamma v \omega \sigma \sigma \varepsilon 1 \varsigma$

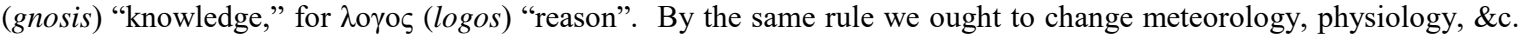
into meteorogony, physiogony, \&c.' (Bakewell 1828, p. 3).

In a passage which refers to "the isochronism of widely extended formations" [emphasis as in original], it continues: "The attempts which have been made by the Hebraic geologists to subject the epochas to absolute measures of time, and to connect the chronology of antient cosmogenic traditions with actual observations of nature, have proved fruitless." (p.28). The slight increase in their usage after 1920 is presumably attributable to twentieth century publications concerning the history of geology. Drawing in part on members of the Askesian Society (1796-1807), which was devoted to general scientific enquiry and the British Mineralogical Society (1799-1806); (Woodward 1908, pp. 6-18). "Physique celeste, qui expliqera la nature des Cieux \& des Astres, \& en Physique Elementaire ou terrestre, qui examinera les corps sublunaires".

"La Physique ou la Connoissance des Corps Naturels $9^{\&}$ de leurs Proprietez. Livre quatrieme. De la Nature \& des proprietez des Corps Terrestres en general". 
La Physique terrestre, ... demande cependant une étude assidue. L'intérieur de notre Globe fournit d'abord le spectacle des Feux souterreins, les Tremblement de terre causes par l'Electricité, les Fossiles, c'est-à-dire, les Métaux, l'Aiman, les Pierres ordinaires \& les pierres précieuses, \&c. [emphasis as in original]. Luc (1792, p. 181); begun in 1773 under the editorship of Jean-François Pilâtre de Rozier (1754-1785), who taught chemistry and physics at the Academy in Reims.

24 Part of the Holy Roman Empire until 1806, when it became part of France.

25 Anonymous (1829, p. 94); almost certainly edited by the German surgeon and publisher, Ludwig Friedrich von Froriep (1799-1874) (Evenhuis 2015). die Wissenschaft der Geologie im weitesten Sinne des Wortes, als allgemeine Naturlehre der Erde (Physik der Erde; Geophysik; theoretische Erdkunde). Such as: Hansteen (1819), Reich $(1834 a, b ; 1838)$, Gauss (1839; English translations in Gauss 1841 and Glassmeier \& Tsurutani 2014), Erman (1835, 1841), Sabine (1838, 1840, 1841, 1842, 1843a,b,c;1844, 1846a,b; 1849, 1851) and Humboldt (1845-1862; English translations in Humboldt 1855-1858, 1868).

28 Such as: Philosophical Transactions of the Royal Society (established 1665); Comptes rendus de l'Académie des Sciences (1666); Göttingischen Gelehrte Anzeigen (1739); Journal de physique, de chimie, d'histoire naturelle et des arts (1787); Annuaire de la Republique Française, présenté au Corps Législatif par le du Bureau des Longitudes (1796); The Quarterly Review (1809); Annales de chimie et de physique (1815); Annalen der Physik und Chemie (1824); London and Edinburgh philosophical magazine and journal of science (1832); and Resultate aus den Beobachtungen des Magnetischen Vereins (1837).

29 He also included celestial mechanics, as pioneered by Pierre-Simon Laplace (1749-1827), Joseph-Louis Lagrange (1736-1813), and Siméon-Denis Poisson (1781-1840) in France; oceanography by John William Lubbock (1803-1865) and William Whewell (1794-1866) in England and Matthew Fontaine Maury (1806-1873) in America; meteorology by Heinrich Wilhelm Dove (1803-1879) in Germany, Ludwig Friedrich Kämtz (1801-1867) and Adolf Theodor de Kupffer (1799-1865) in Russia, and Christopher Hendrick Dirk Buys-Ballot (1817-1890) in Holland. In 1829-1830, Johann Karl Eduard Schmidt (1803-1832), a German mathematician and astronomer, published a two-part work Lehrbuch der mathematischen und physischen Geographie [Textbook of mathematical and physical geography] (Schmidt 1829, 1830), the first volume of which, 'mathematical geography', was concerned with movement and positioning in relation to the Sun and 'fixed' stars; the mathematical projections used to represent the spherical earth on maps; and determination of the degree of flattening ('figure') of the earth from measurement of the lengths of a seconds pendulum at different latitudes. The second volume, 'Physical geography', included sections on the nature of the surface of the earth and its atmosphere; its surface and internal temperature; its geology and internal density; a surprisingly brief discussion of geomagnetism; and the ebb and flow of the seas. Schmidt subsequently became professor of mathematics at the University of Göttingen (1831-1832) and then professor of mathematics, astronomy and physics at the University of Tübingen, Germany, where unfortunately he died soon after his appointment. With the exception of the earth's flattening, the other topics, which we would now include within geophysics, were evidently considered to be part of physical geography.

The first volume of the Beiträge zur Geophysik was devoted to Abhandlungen aus dem geograpischen Seminar der Universität Strassburg [Treatises from the geography seminar of the University of Strasbourg] and described work carried out by members of its research group. In his introduction, Gerland expressed the view that "the methods of geology, so far as they are founded on paleontology, [are not] the proper field of geographical studies", and he confined the latter "to the study of the problems of geophysics: i.e. the study of the physical and chemical forces as acting upon the earth" (Anonymous 1888, p. 203). However, a count of the types of articles in all the issues prior to World War I shows that about $60 \%$ of them were concerned with earthquakes and seismology; $10 \%$ with atmospheric physics and auroral phenomena; $7 \%$ with gravity measurements; $5 \%$ with the shape and constitution of the earth and aspects of terrain morphology; and the rest with vulcanology, geomagnetism, geothermy, etc.

As he approached retirement, from 1899 Gerland shared the role of editor with Emil Julius Friedrich Rudolph (1853-1915), Professor of geophysics, seismology and vulcanology at the University of Strasbourg and from 1910, Rudolph shared his editorial role with the astronomer and geophysicist Oskar Hecker (1864-1938), who had previously worked at the Geodesy Institute in Potsdam and had just been appointed director of the KHES. 